\title{
Odorant Deprivation Reversibly Modulates Transsynaptic Changes in the NR2B-Mediated CREB Pathway in Mouse Piriform Cortex
}

\author{
Hyun H. Kim, Adam C. Puche, and Frank L. Margolis \\ Department of Anatomy and Neurobiology, University of Maryland, School of Medicine, Baltimore, Maryland 21201
}

\begin{abstract}
The olfactory system is an outstanding model for understanding activity-dependent neuronal plasticity in mammals. Olfactory sensory neurons (OSNs) in the periphery project onto mitral/tufted cells in the olfactory bulb $(\mathrm{OB})$ and these mitral/tufted cells in turn project to piriform cortex (PC). Numerous studies have examined changes in OB after a permanent OSN ablation, but little is known about "trans-transsynaptic" changes taking place in the PC. Permanent zinc sulfate lesion of the olfactory epithelium resulted in a selective loss of the NMDA receptor NR2B protein and mRNA expression in pyramidal cells in layer IIb of PC after 2-7 d. Regulatory elements affected by NR2B signaling, namely the phosphorylation of CREB, were also downregulated only in layer IIb neurons. These changes could be caused by OSN axon loss in the zinc sulfate lesion, or to a reduced activity. To test this hypothesis, we performed both permanent and reversible naris occlusion, which blocks odorant access to the nasal cavities and OSN activity. The expression of NR2B and phospho-CREB were downregulated $5 \mathrm{~d}$ after occlusion and this reduction was fully restored $10 \mathrm{~d}$ after reopening of the naris. Subsequently, we identified the subset of pyramidal cells in layer IIb that are especially sensitive to the loss of odor-evoked activity using double retrograde tracers. In summary, the present study provides an initial characterization of the molecular mechanisms associated with odor stimulation on second order neuronal plasticity and phenotype in the olfactory system.
\end{abstract}

Key words: activity dependent; transsynaptic; plasticity; piriform cortex; NMDA receptor; CREB phosphorylation

\section{Introduction}

Peripheral activity-dependent regulation of transsynaptic events in the mammalian cortex have been studied in the visual system (Wiesel and Hubel, 1963; Hubel and Wiesel, 1970) and the somatosensory system (Fox, 1992; Lu et al., 2001; Shepherd et al., 2003). However, this has not been explored previously in detail in the olfactory system. Therefore, our aim was to elucidate activitydependent molecular mechanisms underlying neuronal plasticity in the mouse piriform cortex (PC). Olfactory sensory neurons (OSNs) in the olfactory epithelium (OE) project to the olfactory bulb $(\mathrm{OB})$ where they synapse with target neurons such as mitral and tufted cells that convey olfactory information to higherorder olfactory structures including the piriform cortex. Excitatory synapses in the olfactory system predominantly use glutamate as the neurotransmitter and the major postsynaptic glutamate receptors include NMDA receptors (Trombley and Westbrook, 1990; Wilson, 1995; Ennis et al., 1996; Wilson et al., 1996; Giustetto et al., 1997), AMPA receptors (Montague and Greer, 1999; Hamilton and Coppola, 2003), and the group I metabotropic glutamate receptors (mGluRs) (Duvoisin et al.,

Received April 21, 2006; revised July 27, 2006; accepted Aug. 10, 2006.

This work was supported in part by National Institutes of Health Grant DC-003112 (F.L.M.). We thank Dr. D. Cummings for advice and kindly demonstrating nose plug fabrication, Dr. E. Powell for advice on stereology, Dr. K. Guthrie for sharing an unpublished FJB protocol, Dr. H. Baker for helpful discussions, and F. Scipio for assistance with mice.

Correspondence should be addressed to Dr. Frank L. Margolis, Department of Anatomy and Neurobiology, University of Maryland, School of Medicine, HSF-2 S203, 20 Penn Street, Baltimore, MD 21201.

D0I:10.1523/JNEUROSCI.1727-06.2006

Copyright $\odot 2006$ Society for Neuroscience $\quad$ 0270-6474/06/269548-12\$15.00/0
1995; van den Pol, 1995; Ferraris et al., 1997, Petralia et al., 1997; Casabona et al., 1998; Kinoshita et al., 1998; Wada et al., 1998). NMDA receptors (NRs) are heteromeric (currently thought to be tetrameric) complexes composed of NR1 and NR2 subunits (Ishii et al., 1993; Mori and Mishina, 1995; Luo et al., 1997). Calcium influx through NMDA-type glutamate receptors triggers an increase in the phosphorylation of transcription factor CREB [CAMP-responsive element (CRE)-binding protein] in the nervous system (Lonze and Ginty, 2002; West et al., 2002; Zhu et al., 2002, Thomas and Huganir, 2004).

Peripheral deafferentation and reduced odor-evoked activity causes dramatic morphologic and biochemical changes in the $\mathrm{OB}$ (Margolis et al., 1974; Jin et al., 1996; Ferraris et al., 1997; Casabona et al., 1998; Liu et al., 1999; Fiske and Brunjes, 2001; Hamilton and Coppola, 2003), alteration in synaptic physiology (Brunjes, 1994; Wilson, 1995; Philpot et al., 1997; Franks and Isaacson, 2005), as well as significant changes in neurogenesis of olfactory sensory neurons (Farbman et al., 1988; Cummings et al., 2000). Bulbectomy, which removes the first synapse of the olfactory system and the neurons whose axons project to the PC, results in argyrophilic degenerative changes and cell death of pyramidal neurons in adult rat piriform cortex ipsilateral to the lesion (Heimer and Kalil, 1978; Capurso et al., 1997; Leung and Wilson, 2003). These results have contributed to our understanding of the physiology and anatomy of the olfactory system, based on single-synapse synaptic changes either from $\mathrm{OE}$ to $\mathrm{OB}$ or $\mathrm{OB}$ to PC. The present study was undertaken to elucidate the multisynaptic effects of manipulations of the peripheral part of the 
A

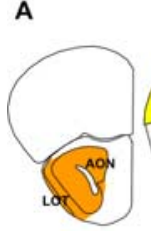

Bregma $2.80 \mathrm{~mm}$

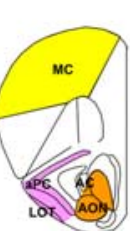

Bregma $2.22 \mathrm{~mm}$
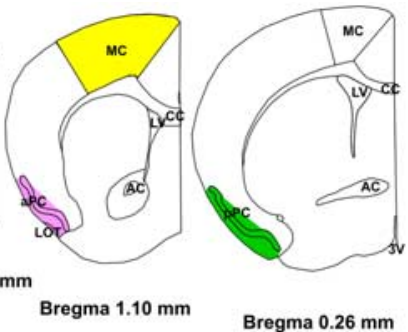

OB
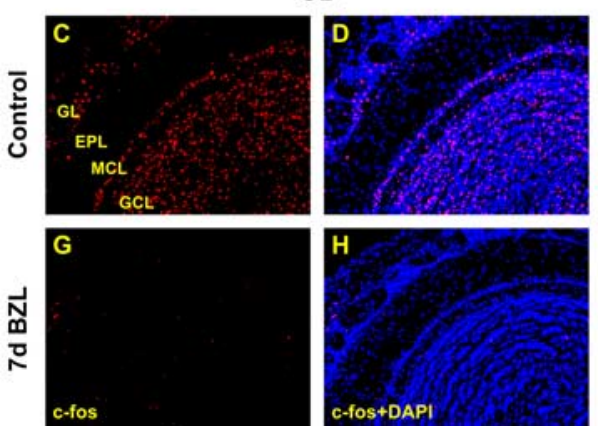
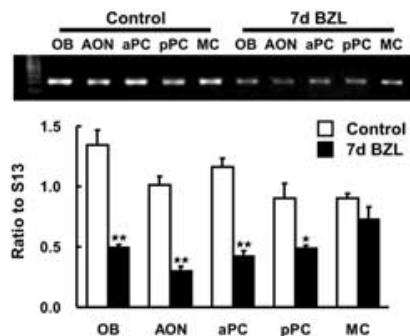

PC
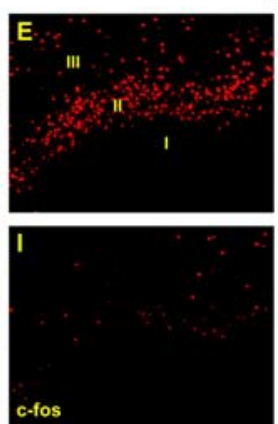
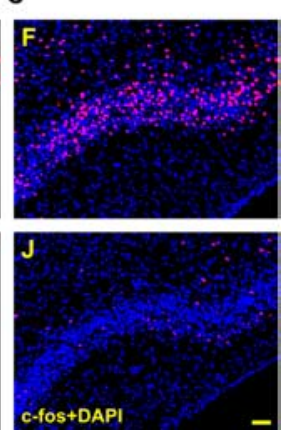

Figure 1. Reduction of c-Fos protein and mRNA expression in $O B$ and $P C$ after bilateral zinc sulfate lesion. $\boldsymbol{A}$, The diagram depicts the areas where we microdissected AON (orange), aPC (pink), pPC (green), and MC (yellow). $\boldsymbol{B}$, The amount of c-fos mRNA was measured by semiquantitative RT-PCR and was reduced $7 \mathrm{~d}$ after bilateral zinc sulfate lesion (BZL) in OB, $A 0 \mathrm{~N}$, aPC, and pPC but not in MC [two-way ANOVA across all tissues and lesions; $F_{(4,30)}=6.80 ; p<0.01$; post hoc Tukey's comparisons revealed significant differences between control and BZL groups in these olfactory tissues $\left({ }^{*} p<0.05 ;{ }^{* *} p<0.01\right)$ ]. Data are means + SEM $(n=4)$. c-Fos immunostaining was visualized by confocal microscopy (red) and nuclei were counterstained with DAPI (blue). $\boldsymbol{C}-\boldsymbol{J}$, Seven days after BZL, C-Fos immunoreactivity was markedly reduced in $\mathrm{OB}(\boldsymbol{G}, \boldsymbol{H})$ and $\mathrm{PC}(\boldsymbol{I}, \boldsymbol{J})$ compared with the control $\mathrm{OB}$ $(\boldsymbol{C}, \boldsymbol{D})$ and $\mathrm{PC}(\boldsymbol{E}, \boldsymbol{F})$. Scale bar, $50 \mu \mathrm{m}$. 3V, Third ventricle; $A C$, anterior commissure; $C$, corpus callosum; EPL, external plexiform layer; GCL, granule cell layer; GL, glomerular layer; LOT, lateral olfactory tract; LV, lateral ventricle; MCL, mitral cell layer.

system on gene expression and histological changes further along the pathway (e.g., in PC) and to explore its underlying molecular mechanism.

\section{Materials and Methods Animals}

All experimental procedures were approved by the University of Maryland Institutional Animal Care and Utilization Committee and conformed to National Institutes of Health guidelines. Mice were transferred to the laboratory at least $24 \mathrm{~h}$ before the treatment or perfusion to avoid activation of c-fos.

Bilateral zinc sulfate lesion. Young adult CD1 mice (6-8 weeks old; male) were administered bilateral intranasal irrigation with $100 \mu \mathrm{l}$ of $5 \%$ $(0.17 \mathrm{M})$ zinc sulfate in $\mathrm{dH}_{2} \mathrm{O}$, by using a $1 \mathrm{cc}$ syringe fitted with a bluntend, polished, 25-gauge needle (Margolis et al., 1974; McBride et al., 2003) and were allowed to survive for 2, 7, or $14 \mathrm{~d}$. Littermates served as sham controls and were irrigated with PBS, pH 7.4. Mice were deeply anesthetized with Nembutal $(50 \mathrm{mg} / \mathrm{kg}$ body weight in $0.9 \%$ saline solution) and briefly perfused transcardially with PBS followed by $4 \%$ freshly depolymerized paraformaldehyde in PBS for $15 \mathrm{~min}$. Brains were stored at $4^{\circ} \mathrm{C}$ in $30 \%$ sucrose for $48 \mathrm{~h}$, embedded in optimal cutting temperature compound (OCT; Sakura Finetek, Torrance, CA) in dry ice and stored at $-80^{\circ} \mathrm{C}$ until used.

Permanent unilateral naris occlusion. CD1 mice (6-8 weeks old; male) were anesthetized by intraperitoneal injection of Nembutal $(50 \mathrm{mg} / \mathrm{kg}$ body weight) and the right naris of each mouse was occluded by electrocautery (Maruniak et al., 1989; Baker et al., 1993). After cauterization, the animals were kept warm and monitored until recovery, and daily thereafter. Two groups of mice at 5 and $10 \mathrm{~d}$ after treatment were anesthetized and perfused as described above and processed for immunohistochemistry (IHC). Efficacy of the occlusion was evaluated by IHC for tyrosine hydroxylase (TH) and c-Fos and mice in which the occlusion was incomplete were not analyzed further.
Reversible unilateral naris occlusion. The nose plug was fabricated as described in Cummings et al. (1997). The plugs were constructed out of polyethylene tubing (PE 50; Becton Dickinson, Parsippany, NJ), silk surgical suture thread (3$0)$, and human hair. Before plug insertion or removal, CD1 mice (6-8 weeks old; male) were anesthetized with halothane. Once the mouse was lightly anesthetized, a plug was coated with a small amount of petroleum jelly and inserted into one naris. After the plug was inserted, the mice were examined to ensure that normal respiration was continuing. For the recovery experiment, each plug was gently removed with forceps after $5 \mathrm{~d}$ and mice were then allowed to recover for an additional $10 \mathrm{~d}$. At the end of this period the mice were anesthetized and perfused transcardially as described above.

\section{Histological procedures}

Immunohistochemistry. Tissue blocks were cut in serial coronal sections $(25 \mu \mathrm{m})$ on a cryostat and rinsed in $0.05 \mathrm{M}$ potassium PBS (KPBS). Floating sections were incubated with blocking solution ( $2 \%$ anti-rabbit serum or $2 \%$ BSA in 0.05 м KPBS containing $0.5 \%$ Triton X-100) for $1 \mathrm{~h}$ at room temperature. They were then incubated with one of the following antibodies diluted in blocking solution at $4^{\circ} \mathrm{C}$ overnight: rabbit anti-c-Fos (1:50,000; Oncogene, La Jolla, CA), mouse anti-NR1 (1:1000; BD PharMingen, San Jose, CA), rabbit anti-NR2A (1:1000; Calbiochem, La Jolla, CA), rabbit anti-NR2B (1:1000; Chemicon, Temecula, CA), rabbit anti-NR2C (1:1000; Chemicon), rabbit antiGluR1 (1:1000; Chemicon), rabbit anti-CREB (1:1500; Upstate, Charlottesville, VA), rabbit anti-phosphorylated (phospho)-CREB (1:1500; Upstate), mouse anti-TH (1:50,000; Incstar, Stillwater, MN), or mouse anti-GFAP (1:200; Boehringer Manheim, Indianapolis, IN). The immunoreactivity was visualized by using either indocarbocyanine (Cy3)-conjugated anti-rabbit secondary antiserum or cyanine (Cy2)-conjugated anti-mouse secondary antiserum (dilution, 1:500; Jackson ImmunoResearch, West Grove, PA). Sections were counterstained by incubation in either $4^{\prime}, 6$ diamidino-2-phenylindole (DAPI) or dimeric cyanine nucleic acid stain (TOTO-3 iodide) for $10 \mathrm{~min}$ at room temperature after immunohistochemical labeling, and coverslipped with fluorescent mounting medium (Dako, Carpinteria, CA).

Amino cupric silver staining. The de Olmos amino cupric silver staining has been reported previously to identify injured neurons in various regions in the brain (Grafe and Leonard, 1980; Yamamoto et al., 1986; de Olmos et al., 1994; Kupina et al., 2002; Hall et al., 2005). Mice were deeply anesthetized and perfused transcardially as described above. Brains in fresh fixative were shipped $\left(4^{\circ} \mathrm{C}\right)$ for histological processing (Neuroscience Associates, Knoxville, TN). Coronal sections ( $35 \mu \mathrm{m}$ ) were silver stained for neuronal degeneration and counter-stained with Neutral Red.

Fluoro-Jade B neuronal degeneration staining. Fluoro-Jade B (FJB), a fluorochrome for the sensitive histochemical localization of neuronal degeneration, was used to identify degenerating neurons (Schumued et al., 1997; Hopkins et al., 2000; Schumued and Hopkins, 2000; Fernandes et al., 2004). Brain sections were mounted on gelatin-coated slides and completely dried. Then sections were rehydrated by incubation in $100 \%$ ethanol for $3 \mathrm{~min}, 70 \%$ ethanol for $2 \mathrm{~min}$, and in distilled water for another $1 \mathrm{~min}$. The slides were incubated in a solution of $0.06 \%$ potassium permanganate for $15 \mathrm{~min}$ on a rotating platform, rinsed in distilled water for $1 \mathrm{~min}$, and transferred to FJB staining solution (0.001\% FJB/ $0.1 \%$ acetic acid, prepared $10 \mathrm{~min}$ before use). After $35 \mathrm{~min}$ in this staining solution, the slides were rinsed three times in distilled water and air dried then immersed in xylene and coverslipped with DPX (Sigma, St. 
Louis, MO), a nonaqueous, nonfluorescent plastic mounting media. This protocol was generously provided by Dr. K. Guthrie (Florida Atlantic University, Boca Raton, FL). Sections stained with FJB were examined with a confocal microscope using a filter system suitable for visualizing FITC.

\section{Semiquantitative RT-PCR}

$\mathrm{OB}$, anterior olfactory nucleus (AON), anterior (aPC) and posterior PC (pPC), and motor cortex (MC) were microdissected under a microscope and collected in Trizol (Invitrogen, Carlsbad, CA). Tissues were stored at $-80^{\circ} \mathrm{C}$ until used for RNA extraction following the manufacturer's protocols. The yields of total RNA were determined by measuring the absorbance ratio at 260/ $280 \mathrm{~nm}$ using an Ultrospec 3000 (Amersham Pharmacia Biotech, Piscataway, NJ). In each region, the same amount of total RNA was used for the reverse transcriptase (RT)-PCR. cDNA was synthesized by denaturation and reverse transcription using random hexamers and Superscript II reverse transcriptase (Invitrogen). c-fos, NR2A, and NR2B were amplified from reversetranscribed cDNA with TaqDNA Polymerase (Invitrogen) in a Bio-Rad (Hercules, CA) programmable thermal cycler with denaturation at $94^{\circ} \mathrm{C}$ for $1.5 \mathrm{~min}$, annealing at $60-66^{\circ} \mathrm{C}\left(\mathrm{c}-f o s, 62^{\circ} \mathrm{C}\right.$; $\mathrm{NR} 2 \mathrm{~A}, 60^{\circ} \mathrm{C}$; NR2B and $2 \mathrm{C}, 61^{\circ} \mathrm{C}$; NR2D, $63^{\circ} \mathrm{C}$; $\mathrm{NR} 1,66^{\circ} \mathrm{C}$ ) for $1.5 \mathrm{~min}$, and extension at $72^{\circ} \mathrm{C}$ for $1.5 \mathrm{~min}$ for 30 cycles $(\mathrm{S} 13,201 \mathrm{bp})$ or 28 cycles (c-fos, 178 bp; NR2A, 403 bp; NR2B, 323 bp). Specific primers designed to amplify mouse ribosomal protein S13 (forward, 5'-CCCCGAGGATCTCTACCATT-3'; reverse, 5'-GCCACTAGACAGAGGCTGT-3'), were used to monitor the quality and quantity of the RNA that had been reverse-transcribed into cDNA. c-fos-specific primers (forward, 5' -CTCCCGTGGTCACCTGTACT-3'; reverse, 5'-TTGCCTTCTCTGACTGCTCA-3'), NR2A-specific primers (forward, 5' -ACCTACTCAGGCCACTTTACCA-3'; reverse, 5'-GAGATTTGCTCCTCTTGCTGTC$3^{\prime}$ ), and NR2B-specific primers (forward, $5^{\prime}$ AAACACGGAACAGGCGATAAG-3'; reverse, 5'-TTAGTCGGGCTTTGAGGGTACT-3' ) were used. Amplified products were separated by agarose gel electrophoresis and the DNA bands visualized by ethidium bromide staining. Band images were visualized in an AlphaImager 3300 (Alpha Innotech, San Leandro, CA), and band intensity was measured and analyzed as the ratio to its companion S13 band intensity. Negative controls for PCR were performed using templates derived from reverse transcription reactions in the absence of reverse transcriptase to confirm the absence of genomic DNA contamination in the RNA.

\section{Retrograde fluorescent labeling}

Adult mice were anesthetized with an intraperitoneal injection of Nembutal (40 mg/kg body weight) and positioned in a stereotaxic apparatus (Stoelting, Wood Dale, IL). To visualize neurons in the piriform cortex projecting to $\mathrm{AON}$, we used cholera toxin- $\beta(\mathrm{CTb} ; 1 \%$ in $0.9 \%$ sodium chloride; List Biologicals, Campbell, CA). After surgical exposure of the olfactory bulbs in mice, $100-200 \mathrm{nl}$ of CTb was injected in the rostral part of AON at stereotaxic coordinates of $3.0 \mathrm{~mm}$ anterior to bregma, 1.25 $\mathrm{mm}$ lateral to sagittal sinus, and $2.5 \mathrm{~mm}$ depth, by means of a glass micropipette and a pneumatic pressure injection apparatus (Picospritzer
NR2B RT-PCR

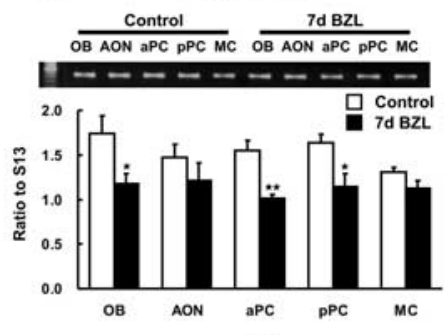

OB
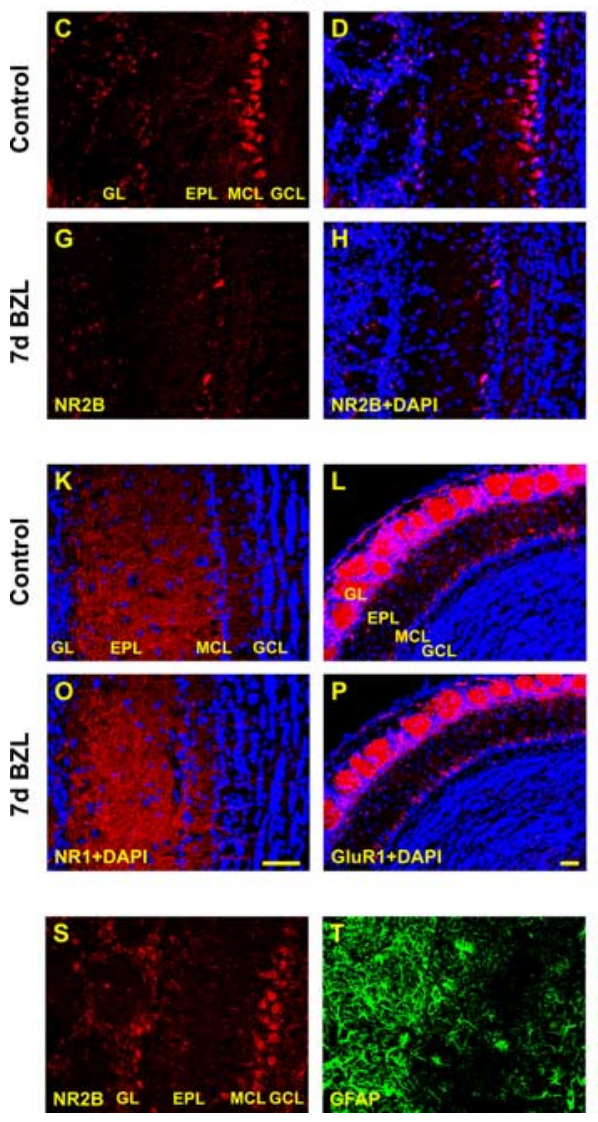

NR2A RT-PCR

Control $7 \mathrm{dBZL}$ $\overline{\mathrm{OB} A O N \text { aPC } \mathrm{PPC} M C} \overline{\mathrm{OB} A O N \text { aPC } \mathrm{PPC} M C}$
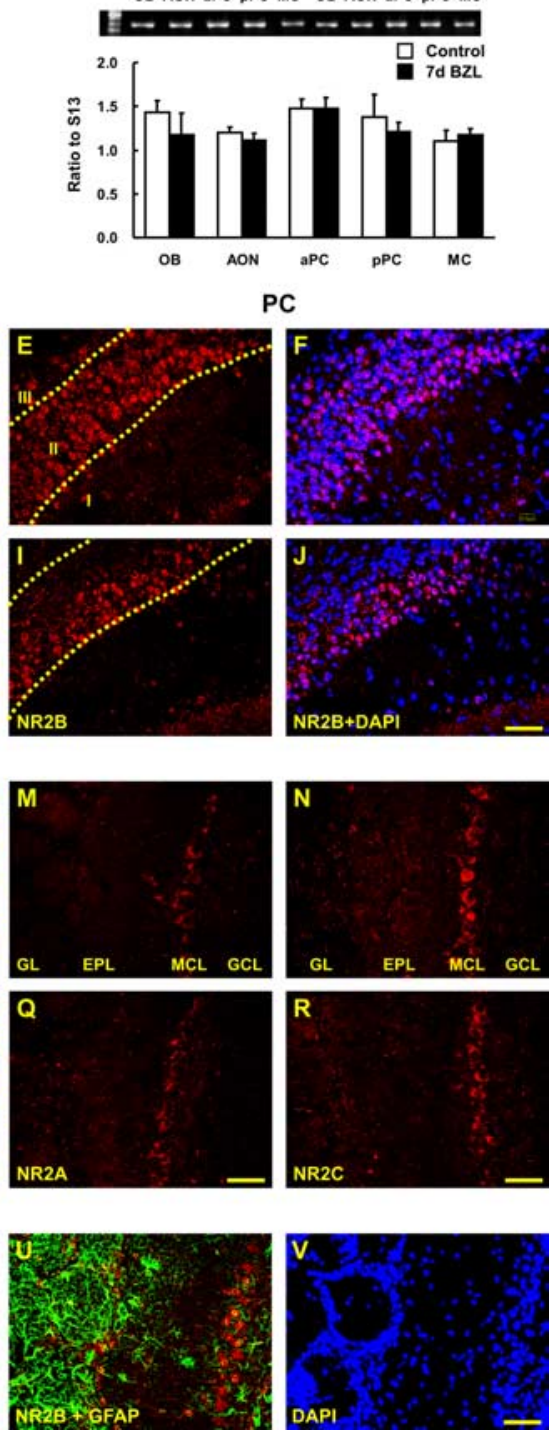

Figure 2. Expression of glutamate receptors in $O B$ and $P C$ after bilateral zinc sulfate lesion. The amount of NR2B and NR2A mRNA expression was measured by semiquantitative RT-PCR. $A, B, N R 2 B$ expression declined $7 \mathrm{~d}$ after bilateral zinc sulfate lesion (BZL) $(\boldsymbol{A})$ in OB, aPC, and pPC [two way ANOVA across all tissues and lesions, $F_{(4,30)}=0.91, p=0.47$, no interaction between lesion and tissue; one-way ANOVA for the main effect of the lesion, $F_{(1,30)}=25.18, p<0.01$; post hoc Tukey's comparisons revealed the significant differences between control and BZL groups in $0 \mathrm{~B}, \mathrm{aPC}$, and $\mathrm{pPC}\left({ }^{*} p<0.05^{* *} p<0.01\right)$ ], whereas NR2A was not significantly affected by BZL $(B)$. Data are means + SEM $(n=4)$. IHC for NR2B, NR1, GluR1, NR2A, and NR2C was visualized by confocal microscopy (red) and nuclei were counterstained with DAPI (blue). $C-J$, Seven days after BZL, NR2B immunoreactivity was markedly reduced in $\mathrm{OB}(\boldsymbol{G}, \boldsymbol{H})$ and only in deep layer $\|(\mathrm{Ilb})$ of $\mathrm{PC}(\boldsymbol{I}, \boldsymbol{J})$ compared with the control $\mathrm{OB}(\boldsymbol{C}$, D) and $P C(\boldsymbol{E}, \boldsymbol{F}) . \boldsymbol{K}-\boldsymbol{R}$, In contrast, NR1, GluR1, NR2A, and NR2C immunostaining $7 \mathrm{~d}$ after BZL $(\boldsymbol{O}-\boldsymbol{R})$ were similar to their controls $(\boldsymbol{K}-\boldsymbol{N})$ in $\mathrm{OB}$ and $\mathrm{PC}$ (data not shown). S, $\boldsymbol{T}, \boldsymbol{V}, \mathrm{OB}$ coronal sections from control were stained for NR2B (S), GFAP $(\boldsymbol{T})$, and DAPI $(\boldsymbol{V})$. $\boldsymbol{U}$, GFAP-positive glial cells were not colabeled with NR2B either in control ( $\boldsymbol{U}$ ) or lesion (data not shown). NR2B and GFAP double labeling demonstrated that astrocytes are not expressing NR2B. Scale bars, $50 \mu \mathrm{m}$. EPL, External plexiform layer; $\mathrm{GCL}$, granule cell layer; GL, glomerular layer; MCL, mitral cell layer.

II; General Valve, Fairfield, IL). To visualize neurons projecting to the OB, we injected 150-200 $\mathrm{nl}$ of 10\% fluorogold (FG; hydroxystilbamidine, methanesulfonate; $1 \%$ in $0.9 \% \mathrm{NaCl}$ ) in multiple areas of the right $\mathrm{OB}$ at stereotaxic coordinates of $4.5 \mathrm{~mm}$ anterior to bregma, 0.7 and 0.8 $\mathrm{mm}$ lateral to sagittal sinus, and $2 \mathrm{~mm}$ depth. At $2 \mathrm{~d}$ postinjection, animals underwent bilateral zinc sulfate lesion as described above. FG is intrinsically fluorescent (blue) but we pseudocolored it violet for better resolution. $\mathrm{CTb}$ was visualized in green using anti-CTb antibody following the immunohistochemistry protocol and sections were counterstained with TOTO-3 iodide (Invitrogen). 
Control
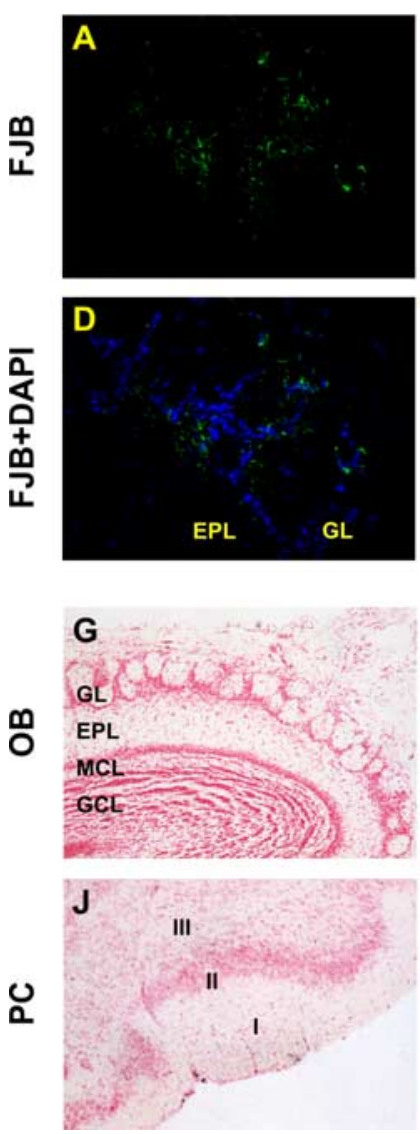

2d BZL
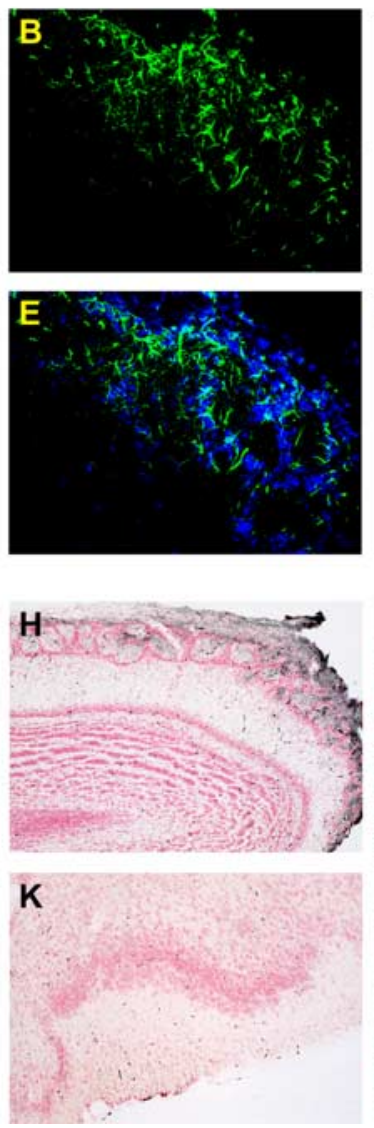

7d BZL
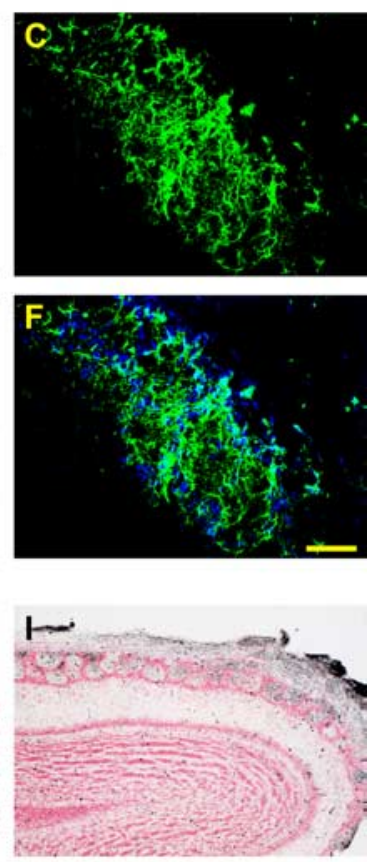

$\mathrm{L}$

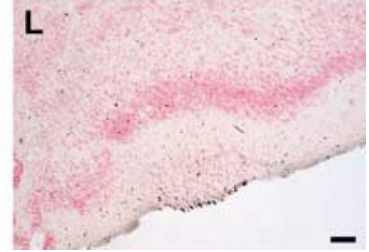

Figure 3. Detection of degenerating neurons in $O B$ and $P C$ after bilateral zinc sulfate lesion. Neuronal degeneration was visualized by FJB staining $(\boldsymbol{A}-\boldsymbol{F}$, green) and amino cupric silver staining ( $\mathbf{G}-\boldsymbol{L}$, black). FJB staining was increased 2 and $7 \mathrm{~d}$ after deafferentation in $O B(B, C)$ compared with control $(\boldsymbol{A})$, but not in $P C$ (data not shown). Two and seven days after, degenerating neurons stained with silver were apparent in $\mathrm{OB}(\boldsymbol{H}, \boldsymbol{I}$, respectively) but not in $\mathrm{PC}(\boldsymbol{K}, \boldsymbol{L})$ compared with the control $\mathrm{OB}(\boldsymbol{G})$ and $\mathrm{PC}$ (J). Scale bars, $50 \mu \mathrm{m}$. EPL, External plexiform layer; $\mathrm{GCL}$, granule cell layer; $\mathrm{GL}$, glomerular layer; $\mathrm{MCL}$, mitral cell layer.

\section{Stereological quantification of immunopositive cell number}

To determine the magnitude of labeled cell density in the piriform cortex after lesion, we compared the density of labeled neurons in the piriform cortex of sham-operated animals $(\mathrm{n}=3)$ and lesioned mice with postlesion survival of 2 or $7 \mathrm{~d}(n=3$ each).

Every ninth serial coronal section (total of three) from each animal was selected, starting at a random level at the beginning of the olfactory cortex, which was $1.1 \mathrm{~mm}$ with respect to bregma (Franklin and Paxinos, 1997) and counted. Image stacks were analyzed by Neurolucida stereology software using the optical dissector counting methodology (Russ and Dehoff, 1999). Cells that are located completely inside the dissector and cells that only cross through its top, right, or back sides are counted. All cells that cross the planes that define the bottom, left, and front sides of the dissector are not counted. Cells in $120,000 \mu \mathrm{m}^{3}$ were counted and the cell density was expressed as cell number in unit volume (cubic millimeters).

\section{Figure preparation and statistics}

Mounted sections for fluorescent labeling were analyzed on a Fluoview 500 confocal microscope (Olympus Instruments, CA) fitted with standard excitation and emission filters for the visualization of Cy2, Cy3, Cy5, DAPI, and TOTO-3. For amino cupric silver staining, light photomicrographs were scanned on a Leica (Nussloch, Germany) DMRX microscope attached to a Phase One (Copenhagen, Denmark) Power Phase digital camera. Images were imported into CorelDraw 12 where they were labeled and the figures assembled.

Data analysis was performed with the KaleidaGraph 4.0 software. For RT-PCR data, statistical analyses were performed by two-way ANOVA to analyze the interaction between lesion and tissue. When we found a significant interaction, we next tested the simple effect of lesion on each tissue. If there was no significant interaction, then we performed one-way ANOVA to evaluate the main effect of the lesion. In both cases, we subsequently tested simple comparisons between each lesion group and its control group with Tukey's honest significant difference (HSD) for the post hoc tests. For the stereological cell counts, each statistical inference was tested by two-tailed Student's $t$ test. For the stereological cell counts using double-retrograde tracing combined with IHC, data were analyzed by two-way ANOVA and Tukey's HSD as described above.

\section{Results}

Peripheral deafferentation by bilateral zinc sulfate irrigation caused reduction of c-fos expression

Localization of both c-fos mRNA and protein has proven to be useful for identification of activated neurons in a number of brain regions, including the olfactory bulb (Guthrie et al., 1993; Illig and Haberly, 2003). Peripheral deafferentation reduces olfactory input to the olfactory bulb and, thus, expression of c-fos. Reduced input to the olfactory bulb should also result in reduced cortical input and c-fos expression in the piriform cortex. c-fos mRNA expression was examined in microdissected tissues from $\mathrm{OB}, \mathrm{AON}, \mathrm{aPC}$ and $\mathrm{pPC}$, and MC (Fig. $1 A)$. RNA isolated from those tissues was used to perform semiquantitative RT-PCR and the amount of amplicon was expressed as the ratio of each tissue's c-fos band intensity to ribosomal protein S13 intensity as an internal standard (Fig. $1 B$ ). Expression of c-fos was significantly $(p<0.01)$ reduced in $\mathrm{OB}, \mathrm{AON}$, and PC 1 week postlesion but unaffected in "nonolfactory" tissues (i.e., motor cortex) (Fig. $1 B$ ). This result is consistent with overall reduced activity in the olfactory pathway as a consequence of peripheral neuronal loss, however, activity changes could be selective to different classes of neurons in these regions. To test for selective changes in $c$-fos, we stained for c-Fos protein (Fig. 1C-J). As expected, we observed the global reduction of c-Fos expression in the olfactory bulb 1 week postlesion (Fig. 1G,H). In the piriform cortex, pyramidal cell c-Fos expression was severely diminished in all piriform cortical layers and cell types 1 week postlesion (Fig. $1 I, J$ ). These results demonstrate that peripheral deafferentation reduces global neural activity, as measured by c-fos expression, throughout the olfactory pathway.

\section{NMDA receptor expression is altered in $\mathrm{OB}$ and $\mathrm{PC}$ after peripheral deafferentation}

Changes in expression of the immediate early gene c-fos implies changes in activity in the first- and higher-order synapses in the pathway. We hypothesize these changes are accompanied by alterations in the regulation of neurotransmitter receptors. Because excitatory output neurons in the olfactory system use glutamate as their major excitatory neurotransmitter molecule 
Control
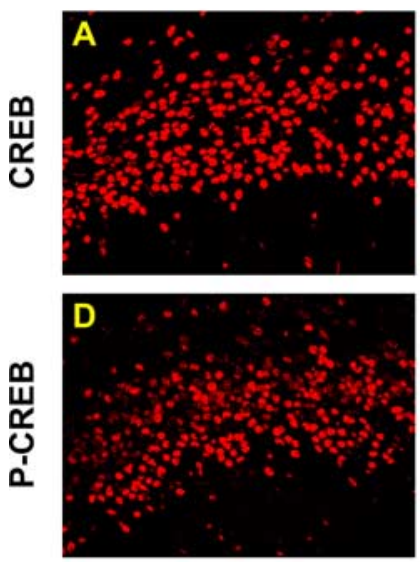

2d BZL
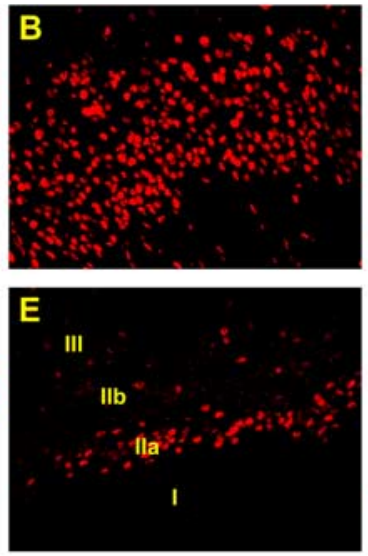

7d BZL
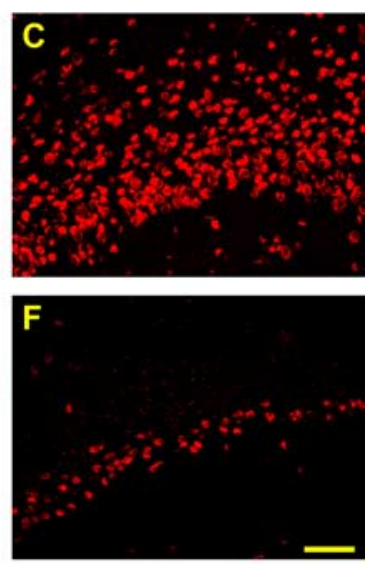

G

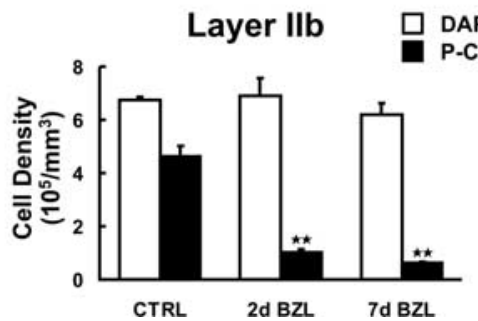

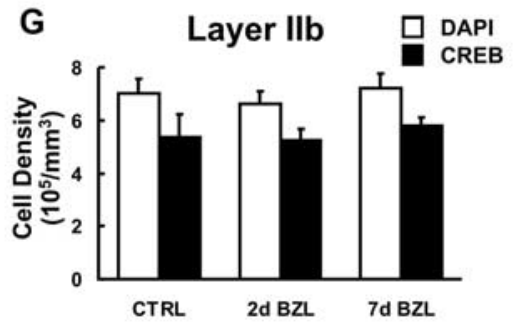

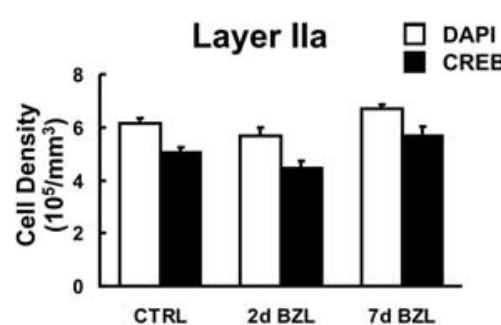

Layer Ila

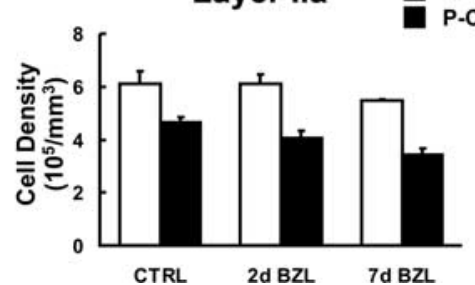

Figure 4. Expression of CREB and phospho-CREB (p-CREB) protein after bilateral zinc sulfate lesion. $A-F$, CREB and phosphoCREB expression was visualized by immunostaining (red) in $\mathrm{PC}$ of control mice $(\boldsymbol{A}, \boldsymbol{D})$, and $2 \mathrm{~d}(\boldsymbol{B}, \boldsymbol{E})$ and $7 \mathrm{~d}(\boldsymbol{C}, \boldsymbol{F})$ after bilateral zinc sulfate lesion (BZL). $\mathbf{G}$, The density of total nuclei and CREB/phospho-CREB-positive cells per unit volume was stereologically quantified in layers Illa (right) and Illb (left) for CREB (top) and phospho-CREB (bottom). Two and seven days after BZL, phosphoCREB immunoreactivity was markedly reduced in layer $\mathrm{Ilb}(\boldsymbol{E}, \boldsymbol{F})$ whereas $(\mathrm{REB}$ immunoreactivity was not changed $(\boldsymbol{B}, \boldsymbol{C})$ compared with the controls $\left.(\boldsymbol{D}, \boldsymbol{A}){ }^{* *} p<0.01\right)$. Data are means + SEM $(n=3)$. Scale bar, $50 \mu \mathrm{m}$.

(Trombley and Westbrook, 1990; Berkowicz et al., 1994), we monitored expression of NMDA (NR1, 2A, 2B, 2C, and 2D subunits) and AMPA-type receptors (GluR1) in $\mathrm{OB}$ and $\mathrm{PC}$ after zinc sulfate irrigation using semiquantitative RT-PCR (Fig. 2). Peripheral deafferentation resulted in downregulation of the NMDA NR2B subunit expression in OB (first synapse; $p<0.05$ ) and PC (second or higher order synapse; $p<0.01$ ) after $7 \mathrm{~d}$ (Fig. $2 A$ ). Expression of the other NMDA subunits (NR1, 2A, 2C, and 2D) and AMPA receptor (GluR1) was unchanged (representative data shown only for NR2A in Fig. $2 B$ ). The global reduction in $\mathrm{c}$-fos expression in bulb and piriform cortex suggested that the NR2B downregulation could occur equally in all neurons. Immunohistochemistry for NR2B in the OB showed a uniform loss of the subunit in all bulb layers, however, there was a striking selectivity in subunit downregulation in layer IIb of piriform cortex $7 \mathrm{~d}$ post lesion with no apparent change in layer IIa (Fig. $2 I, J$ ). Immunohistochemistry for NR1 (Fig. $2 K$ ), GluR1 (Fig. $2 L$ ), NR2A (Fig. 2M), and NR2C (Fig. $2 N$ ) was identical in lesion and control tissues supporting our RT-PCR results. Together, these data suggest transsynaptic reduction in gene expression in PC is NR2B-specific.

The NR2B subunit of the NMDA receptor can be expressed in glia where it has been suggested to play a role in mediating injury responses (Salter and Fern, 2005; Kato et al., 2006). Alterations in NR2B expression after lesion could therefore be occurring in glia rather than neurons. However, in the $\mathrm{OB}$ and $\mathrm{PC}$, astrocytes (identified by GFAP immunostaining) did not express detectable NR2B in control (Fig. $2 U$ ) or $7 \mathrm{~d}$ postlesion sections (data not shown). In addition, there was no indication of reactive gliosis and GFAP upregulation in PC after lesion (data not shown). This indicates that the transsynaptic changes in gene expression that we observed in the PC are not caused by the induction of astrocytes but are neuronal specific.

Reductions in NR2B in the PC could be the result of downregulation of the gene or neural cell death selective to layer IIb. Neurodegeneration was examined by Fluoro-Jade B (FJB) staining, which recognizes degenerating neurons (Fernandes et al., 2004). Coronal sections stained with FJB showed increased cell death at 2 and $7 \mathrm{~d}$ in $\mathrm{OB}$ (Fig. $3 \mathrm{~B}, \mathrm{C}$ ) compared with control $(A)$ but not in PC (data not shown). An alternate approach to examining neurodegeneration involves the de Olmos amino cupric silver histochemical technique (Grafe and Leonard, 1980; Yamamoto et al., 1986; de Olmos et al., 1994; Kupina et al., 2002; Hall et al., 2005). This silver stain identifies degenerating neural processes and was increased in the $\mathrm{OB}$ at 2 and $7 \mathrm{~d}$ after lesion (Fig. $3 \mathrm{H}, I$ ) but not in the PC $(K, L)$. These results demonstrate that no major degenerative pyramidal cell loss is occurring in the PC after deprivation and further indicate that the reduction in NR2B in the PC is not caused by degeneration. A small amount of degeneration was observed in the lateral olfactory tract at $7 \mathrm{~d}$ postlesion, consistent with previous observations that mitral cells degenerate after deafferentation (Margolis et al., 1974). Thus, deafferentation induces degeneration in OB, but not in PC neurons, and this was also supported by subsequent DAPIpositive cell counts, which show no significant changes either in layers IIa or IIb after deprivation (Fig. 4G). In conclusion, these results indicate the absence of neuronal degeneration in mouse PC after peripheral deafferentation and imply that changes in gene expression are activity dependent.

\section{Coordinate regulation of NR2B and phospho-CREB}

Activation of the NMDA receptor by glutamate leads to calcium influx through the receptor and subsequent membrane depolarization. In addition to this electrophysiological role, activation of the NMDA receptor can trigger changes in CREB phosphorylation and subsequent gene expression (Bito, 1998; Lonze and Ginty, 2002; West et al., 2002; Zhu et al., 2002). NR2B is impor- 
tant for the NMDA-mediated signaling pathway (Thomas and Huganir, 2004) and we hypothesized that downregulation of this subunit would lead to alterations in the phosphorylation of CREB. To evaluate whether changes in NR2B affect the downstream signaling molecule CREB and phospho-CREB, we stained the PC of control and lesioned mice with CREB and phospho-CREB antibodies (Fig. 4). The number of immunoreactive cells in layer IIa and IIb of PC were quantified with optical dissector stereology methodology (Figs. 4G). CREB and phospho-CREB were widely expressed by cells in layers IIa and IIb of PC (Fig. $4 A, D$ ). We observed a reduction in phospho-CREBimmunoreactive pyramidal cells only in layer IIb and not IIa at 2 and $7 \mathrm{~d}$ after zinc sulfate lesion (Figs. 4E,F) $(p<0.01)$. However, CREB immunostaining remained unchanged after lesion (Figs. $4 B, C)$, suggesting alterations in CREB activation and phosphorylation rather than expression. Together, these data indicate a pathway whereby peripheral lesion reduces glutamatergic input and neural activity in the $\mathrm{OB}$, input and neural activity in the PC, reduction in the phosphorylation of CREB in layer IIb neurons, and expression of NMDA receptor subunit $\mathrm{NR} 2 \mathrm{~B}$ in layer IIb and putatively other genes.

\section{NR2B is selectively lost from only the pyramidal cells projecting to the $\mathrm{OB}$}

The piriform cortex is divided into layers I, IIa, IIb, and III based on structure and synaptic connections (Haberly and Price, 1978). Retrograde tracing studies in rat demonstrated that pyramidal cells in layers IIb and III project to the OB and synapse primarily onto granule cells, with virtually no pyramidal cells in layer IIa projecting to the $\mathrm{OB}$. In contrast, pyramidal cells in layer IIa have a strong projection to the AON (Haberly and Price, 1978). However, it has never been determined whether mouse PC layer IIa and IIb neurons have similar segregated projections. Therefore, we used double retrograde tracing to confirm the differential projection of the two subsets of pyramidal cells in layers IIa and $\mathrm{IIb}$ in mouse. The retrograde tracer FG was injected into the $\mathrm{OB}$ (Fig. 5A, arrowhead) and the retrograde tracer $\mathrm{CTb}$ injected into AON (Fig. 5E, arrowhead). FG-labeled cells were present predominantly in layer IIb (Fig. 5G, violet) whereas CTb-labeled cells were mainly in layer IIa (Fig. $5 \mathrm{H}$, green). However, in mouse there is not a strict anatomical boundary between these two subsets of pyramidal cells so at the border between layers IIa and IIb pyramidal cells with different projections intermingle. Cells labeled with tracers and TOTO-3 were stereologically counted (Fig. $5 M)$. The tracer-labeled cell density measurements between layers IIb and IIa were significantly different $(p<0.01$, two-tailed Student's $t$ test). TOTO-3 labeled cell counts exhibit lower cell density in layer IIa as described previously (Shipley and Ennis, 1996).

The previous experiments demonstrated that mouse pyramidal cells generally segregate into layers IIa and IIb on the basis of projections, with IIa neurons having projections to the AON and IIb projections to the OB. NR2B and phospho-CREB expression changes selectively in layer IIb, which suggests pyramidal cells that project to the bulb selectively lose NR2B. To test this hypothesis, we labeled pyramidal cells with dual retrograde tracers FG (violet) and $\mathrm{CTb}$ (green) and immunostained for either CREB or phospho-CREB (Fig. 6). In control animals, CREB and phosphoCREB were expressed in retrogradely labeled pyramidal cells in both layer IIa and IIb (Fig. $6 F, N$, respectively). After peripheral deafferentation, cells in layer IIa that were retrogradely labeled from the AON with $\mathrm{CTb}$ exhibited no reductions in phospho-CREB (Fig. 6P). However, we found a peripheral deafferentation-induced reduction of CREB-phosphorylation only in FG labeled cells (i.e., those pyramidal cells projecting to the OB) (Fig. 6P). Stereological cell counts revealed a significant decrease in phospho-CREB-labeled cell density after lesion and this reduction was observed only in FG-labeled cells (Fig. 6Q) $(p<0.01)$. Thus, NR2B and phospho-CREB are altered in pyramidal cells providing feedback to the $\mathrm{OB}$ but not in pyramidal cells of the associative connections with AON.

\section{NR2B and phospho-CREB downregulation is activity dependent}

After peripheral deafferentation, the changes observed in the PC could be the result of some unknown trophic factor dependence on the olfactory nerve, which is absent as a result of the lesion, or on a reduction in glutamatergic input to the $\mathrm{OB}$ and the rest of the olfactory system. To determine whether the changes we observed in gene expression are activity-dependent, we used unilateral permanent naris occlusion. This manipulation reduces access of odor stimuli to OSNs in the closed naris with a concomitant 


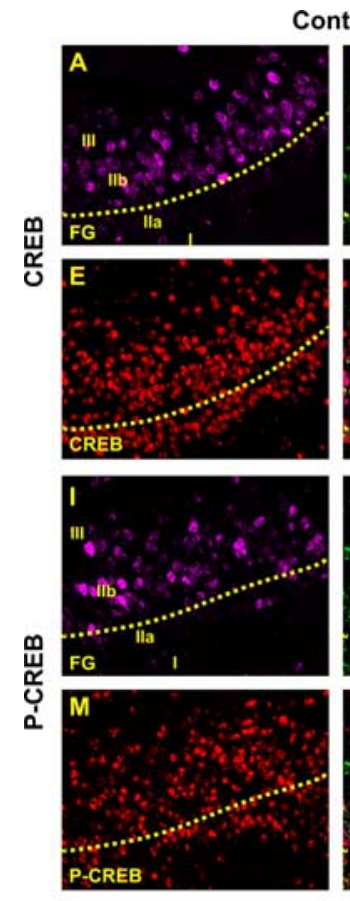

Control
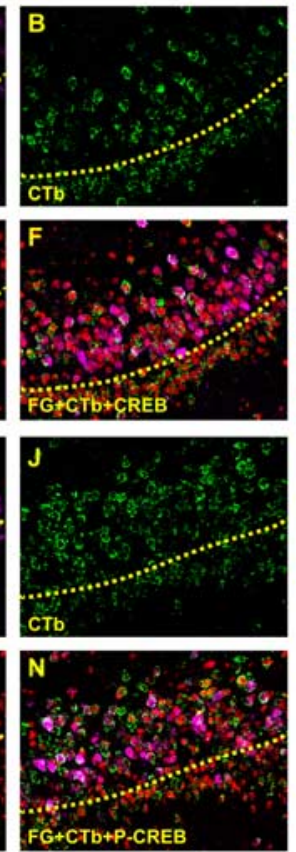

Q
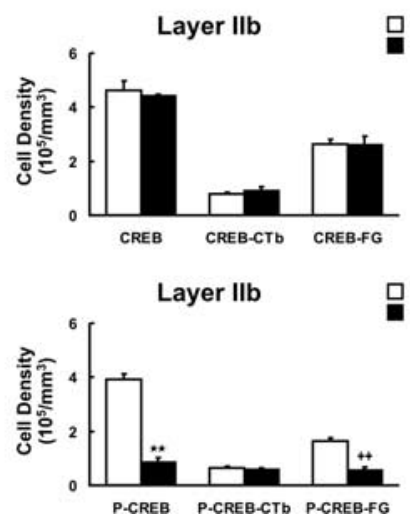

$7 \mathrm{~d}$ BZL
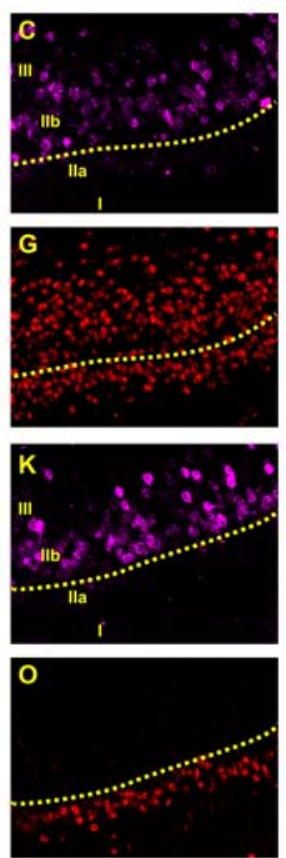
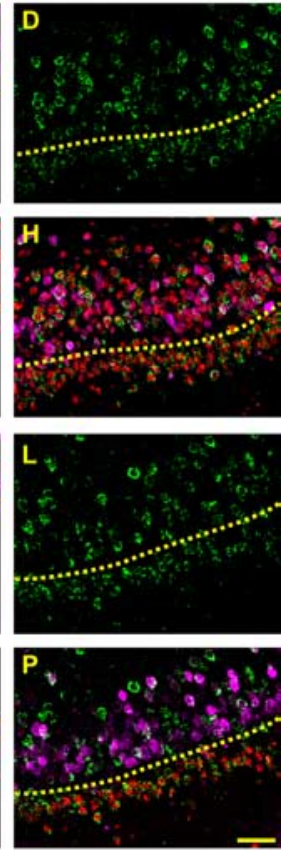

Layer Ila
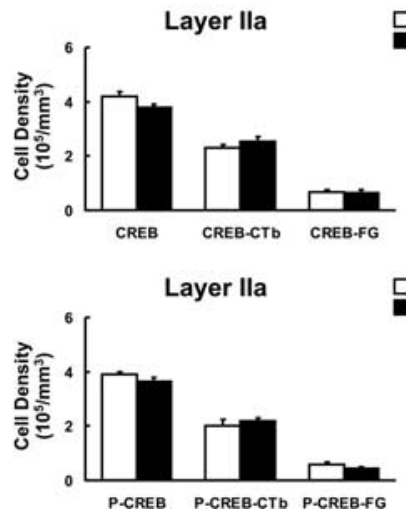

Figure 6. Phosphorylation of CREB in $\mathrm{FG}$ - and CTb-labeled pyramidal cells after deafferentation. $\boldsymbol{A}-\boldsymbol{E}, \mathbf{G}, \mathbf{I}-\boldsymbol{M}, \mathbf{O}, \mathrm{FG}$ - (violet; $\boldsymbol{A}$, $\boldsymbol{C}, \boldsymbol{I}, \boldsymbol{K})$ and $(\mathrm{Tb}$-labeled (green; $\boldsymbol{B}, \boldsymbol{D}, \boldsymbol{J}, \boldsymbol{L})$ pyramidal cells were colabeled with CREB $(\boldsymbol{E}, \boldsymbol{G})$ and phospho-CREB (p-CREB; $\boldsymbol{M}, \boldsymbol{O})$ antibody (red). $\boldsymbol{F}, \boldsymbol{H}$, Pyramidal cells traced by $\mathrm{FG}$ and $(\mathrm{Tb}$ were both stained with CREB either in control $(\boldsymbol{F})$ or at $7 \mathrm{~d}$ after bilateral zinc sulfate lesion (BZL) $(\boldsymbol{H}) . \boldsymbol{N}, \boldsymbol{P}$, Sections were also double labeled with phospho-CREB in control $(\boldsymbol{N})$ and $7 \mathrm{~d}$ after BZL $(\boldsymbol{P})$. The subset of pyramidal cells labeled with FG lost phospho-CREB labeling after BZL and most of these cells are located in layer Ilb whereas (Tb-labeled cells in layer lla still express phospho-CREB even after zinc sulfate lesion $(\boldsymbol{P})$. $\mathbf{Q}$, Stereological cell counts revealed a significant decrease in phospho-CREB- and FG-double-labeled cell density after zinc sulfate lesion $\left({ }^{* *} p<0.01\right.$; $\left.{ }^{++} p<0.01\right)$. Data are means + SEM $(n=3)$. Scale bar, $50 \mu \mathrm{m}$.

reduction in synaptic activity from the OSNs to the $\mathrm{OB}$ and $\mathrm{PC}$ but avoids any direct damage to OSNs. We occluded one naris of adult mice by electrocautery and allowed the mice to survive for either 5 or $10 \mathrm{~d}$. Sections from OB were immunostained for $\mathrm{TH}$, the rate limiting enzyme for dopamine biosynthesis and for c-Fos, and PC sections only for c-Fos. TH is normally expressed in juxtaglomerular cells of the OB (Halasz et al., 1977), and dramatically decreases after peripheral lesions including unilateral naris occlusion (Nadi et al., 1981; Baker et al., 1983; Stone et al., 1990). A reduction in TH immunoreactivity (more than fivefold change) was used as the "gold standard" for an effective naris occlusion (supplemental Fig. $1 F$, available at www.jneurosci.org as supplemental material). As expected, c-Fos immunoreactivity was reduced in the OB (supplemental Fig. $1 E$, available at www. jneurosci.org as supplemental material) and in the PC (supple- mental Fig. $1 G$, available at www.jneurosci.org as supplemental material) ipsilateral to naris occlusion, but not in the contralateral $\mathrm{OB}$ or $\mathrm{PC}$ where the naris was open (supplemental Fig. 1C, available at www.jneurosci.org as supplemental material). These results confirm an effective naris occlusion that results in decreased peripheral input to the $\mathrm{OB}$ and $\mathrm{PC}$.

We next examined NR2B (Fig. 7A-H) and phospho-CREB expression (Fig. 7I-O) to determine whether the reduction of NR2B/phospho-CREB expression in the PC observed after peripheral deafferentation was caused by OSN destruction or to an activity-dependent process. After naris occlusion, expression of NR2B and phospho-CREB was reduced specifically in layer IIb of the ipsilateral PC whereas CREB expression was unchanged. The control contralateral PC showed no significant changes in NR2B, CREB, or phospho-CREB expression. Comparing the ratio of phospho-CREB and CREB in layer IIb of the ipsilateral and contralateral PC showed a highly significant reduction in phospho-CREB (Fig. 7O) $(p<0.01)$. The magnitude of reduction $(75 \%)$ was less than in zinc sulfate treated mice $(85 \%)$ and this might be because of the unilateral occlusion and/or the presence of spontaneous activity remaining after naris occlusion. These results demonstrate that changes in NR2B and phospho-CREB are principally the result in reduced neural activity within the olfactory pathway.

\section{NR2B and phospho-CREB} downregulation is restored on reversal of naris occlusion

To unambiguously demonstrate that the alterations in NR2B gene expression and CREB phosphorylation are caused by an activity-dependent process, it is essential to demonstrate reversal and recovery after activity returns. To achieve this, we used the technique of unilateral olfactory nose plugs (Cummings et al., 1997). These plugs effectively occlude the naris while in place, but can be removed to "reopen" the naris at selected times. Unilateral nose plugs remained in place for $5 \mathrm{~d}$, which is sufficient to induce changes in NR2B and CREB phosphorylation. Animals examined at $5 \mathrm{~d}$ showed the expected reduction in $\mathrm{TH}$ and $\mathrm{c}-\mathrm{Fos}$ in the $\mathrm{OB}$ and PC (supplemental Fig. $1 \mathrm{~N}, \mathrm{O}$, available at www.jneurosci.org as supplemental material). Ten days after plug removal the $\mathrm{OB}$ and $\mathrm{PC}$ were examined for $\mathrm{TH}$ and c-Fos expression. Both of these activity markers show full recovery $10 \mathrm{~d}$ after plug removal (supplemental Fig. $1 R, S$, available at www.jneurosci.org as supplemental material), demonstrating "rescue" of neural activity in the olfactory system by naris reopening.

With this highly effective model of activity deprivation and rescue, we next examined the ability of NR2B and phosphoCREB to be recovered in PC layer IIb when activity is restored to 
the olfactory system. The expression of NR2B and phospho-CREB in animals with a $5 \mathrm{~d}$ plug was identical to animals at $5 \mathrm{~d}$ after a permanent naris occlusion (i.e., NR2B) (Fig. 8G) and phospho-CREB were downregulated in PC layer IIb neurons (Fig. 8Q). However, $10 \mathrm{~d}$ after the naris was reopened, expression of phosphoCREB recovered to almost the same CREB/phospho-CREB ratio as in controls (Fig. $8 R$ ). NR2B expression was also recovered to the same extent as control in the $\mathrm{OB}$ and $\mathrm{PC}$ at $10 \mathrm{~d}$ after plug removal (Figs. $8 I, K)$. Together, these data demonstrate neural activity from the periphery regulates CREB-phosphorylation and NR2B expression in the trans-transsynaptic target of pyramidal neurons in piriform cortex layer IIb.

\section{Discussion}

In this study, using a combination of deafferentation and permanent and reversible sensory deprivation, we show that peripheral sensory stimulation of the olfactory epithelium transsynaptically regulates expression of the NMDA receptor NR2B subunit and phosphorylation of CREB in the olfactory bulb and piriform cortex. Expression of the NR2B subunit of the NMDA receptor is selectively affected only in neurons of layer IIb of the piriform cortex. In contrast, expression of these genes in the more superficial layer IIa is unaltered by sensory deprivation.

\section{Deafferentation, neural activity, and cell death}

Cortical neurons are surprisingly tolerant to experimental lesions such as axotomy (Koliatsos and Price, 1996), but long term survival is often highly dependent on trophic factors released by target tissues (Ehlers et al., 1995; de Freitas et al., 2001). Bulbectomy, a process in which the olfactory bulb is surgically ablated, axotomizes pyramidal neurons in the cortex, which project to the bulb along the centrifugal fiber tract, and also removes inputs to the pyramidal neurons that derive from the bulb and causes apoptotic death of cortical neurons in adult rats (Heimer and Kalil, 1978; Capurso et al., 1997; Koliatsos et al., 2004). Ablation of the sensory epithelium with zinc sulfate deafferents the olfactory bulb and results in $\mathrm{OB}$ cell death as seen with our amino cupric silver and FJB staining (Fig. 3). This OB cell death is consistent with previous studies (Najbauer and Leon, 1995; Cummings et al., 1997; Fiske and Brunjes, 2001). Peripheral deafferentation did not cause any changes in amino cupric silver staining, FJB staining, cell density, or proportions of retrogradely labeled pyramidal neurons in the piriform cortex, indicating that there is no significant transsynaptic cell death in mouse within the time frame of our experiments. In contrast, in rat, unilateral naris closure is reported
OB
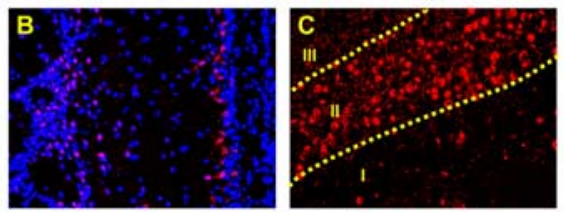

PC
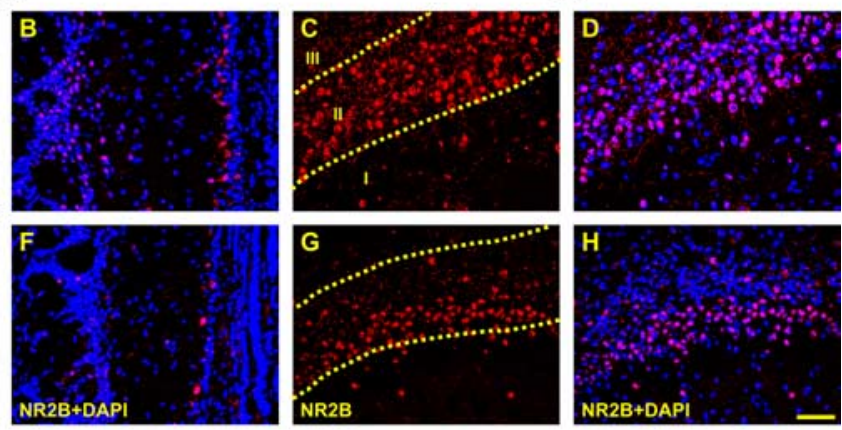

10d PNO
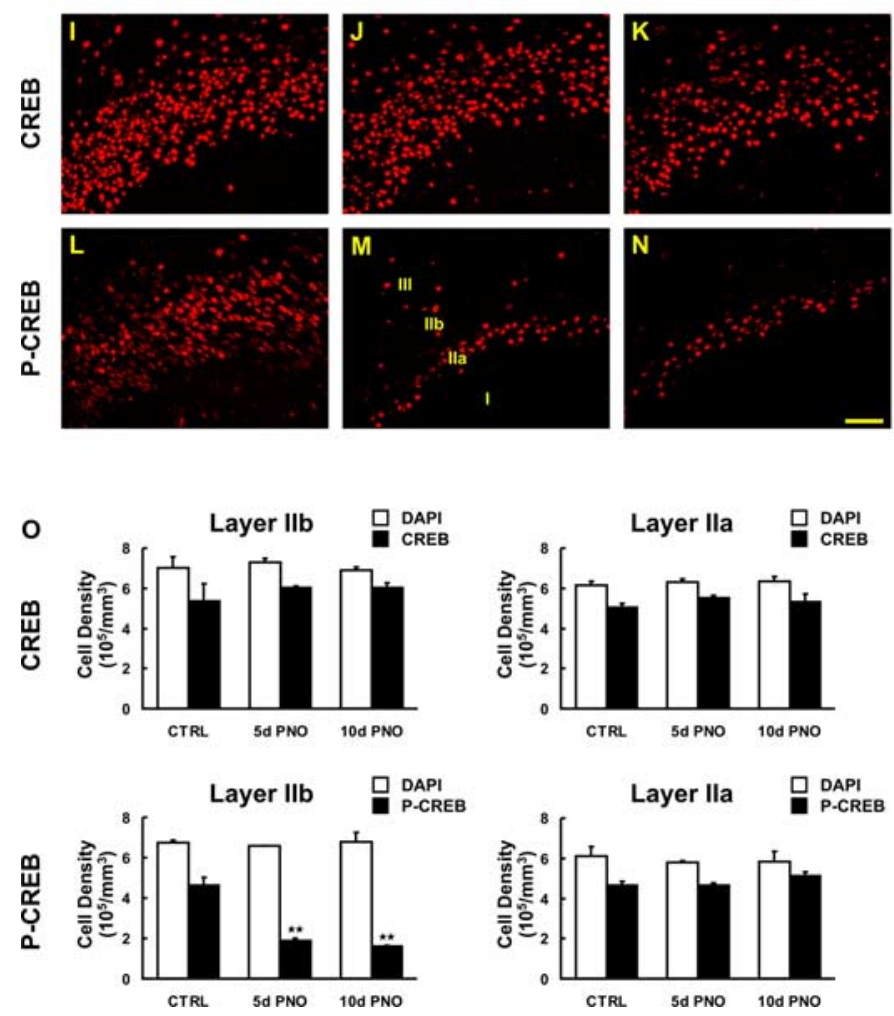

Figure 7. Activity-dependent changes in expression of NR2B and phosphorylation of CREB after permanent naris occlusion. Sections of mouse brain taken after 5 and $10 \mathrm{~d}$ of permanent naris occlusion (PNO) were processed for NR2B, CREB, and phosphoCREB (p-CREB) IHC. $\boldsymbol{A}-\boldsymbol{H}$, Reduction in NR2B immunoreactivity was observed in the deprived bulb $(\boldsymbol{E}, \boldsymbol{F})$ and its ipsilateral PC $(\boldsymbol{G}, \boldsymbol{H})$ compared with the undeprived bulb $(\boldsymbol{A}, \boldsymbol{B})$ and its $\mathrm{PC}(\boldsymbol{C}, \boldsymbol{D})$. Note that a major reduction was seen only in Ilb. I-N, CREB and phospho-CREB-positive pyramidal cells were visualized (red) in PC from control $(\boldsymbol{I}, \boldsymbol{L}), 5 \mathrm{~d}(\boldsymbol{J}, \boldsymbol{M})$ and $10 \mathrm{~d}(\boldsymbol{K}, \boldsymbol{N})$ after PNO. O, The density of total nuclei and CREB/phospho-CREB-positive cells in unit volume was stereologically quantified in layers lla (right) and Ill (left) for CREB (top) and phospho-CREB (bottom). Phospho-CREB immunoreactivity was markedly reduced 5 and $10 \mathrm{~d}$ after PNO $(M, N)$, and the reduction was restricted to layer $\mathrm{llb}$. However, CREB immunostaining was unchanged after PNO $(\boldsymbol{J}, \boldsymbol{K})$ compared with the control $(I)\left({ }^{* *} p<0.01\right)$. Data are means + SEM $(n=3)$. Scale bar, $50 \mu \mathrm{m}$.

to increase TUNEL (terminal deoxynucleotidyl transferasemediated biotinylated UTP nick end labeling)-positive cell counts in the piriform cortex (Leung and Wilson, 2003). However, in our study, $21 \mathrm{~d}$ of unilateral naris occlusion does not appear to cause drastic cell death in the piriform cortex of mouse (our unpublished observation), possibly reflecting a species difference in neural sensitivity.

\section{Activity-dependent transsynaptic plasticity}

Neural activity regulates the expression of many genes throughout the nervous system. In the olfactory system, alterations of peripheral sensory input, either by deafferentation (Margolis et al., 1974; Baker et al., 1988; Ferraris et al., 1997; Casabona et al., 
OB
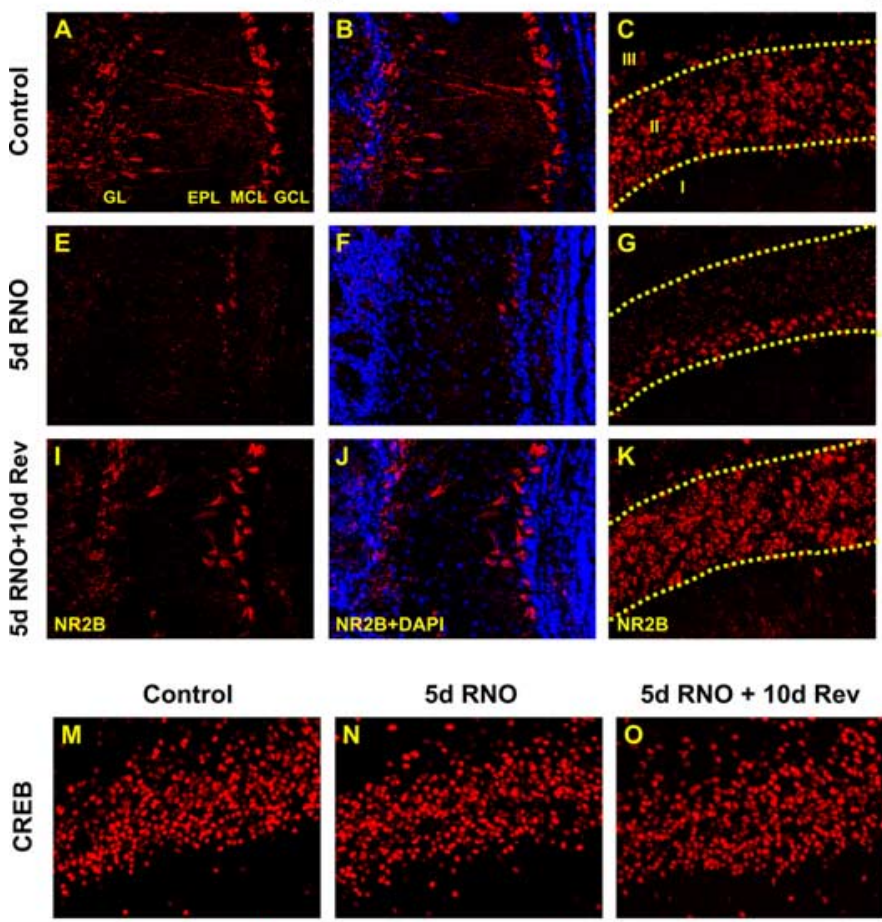

$\mathrm{PC}$
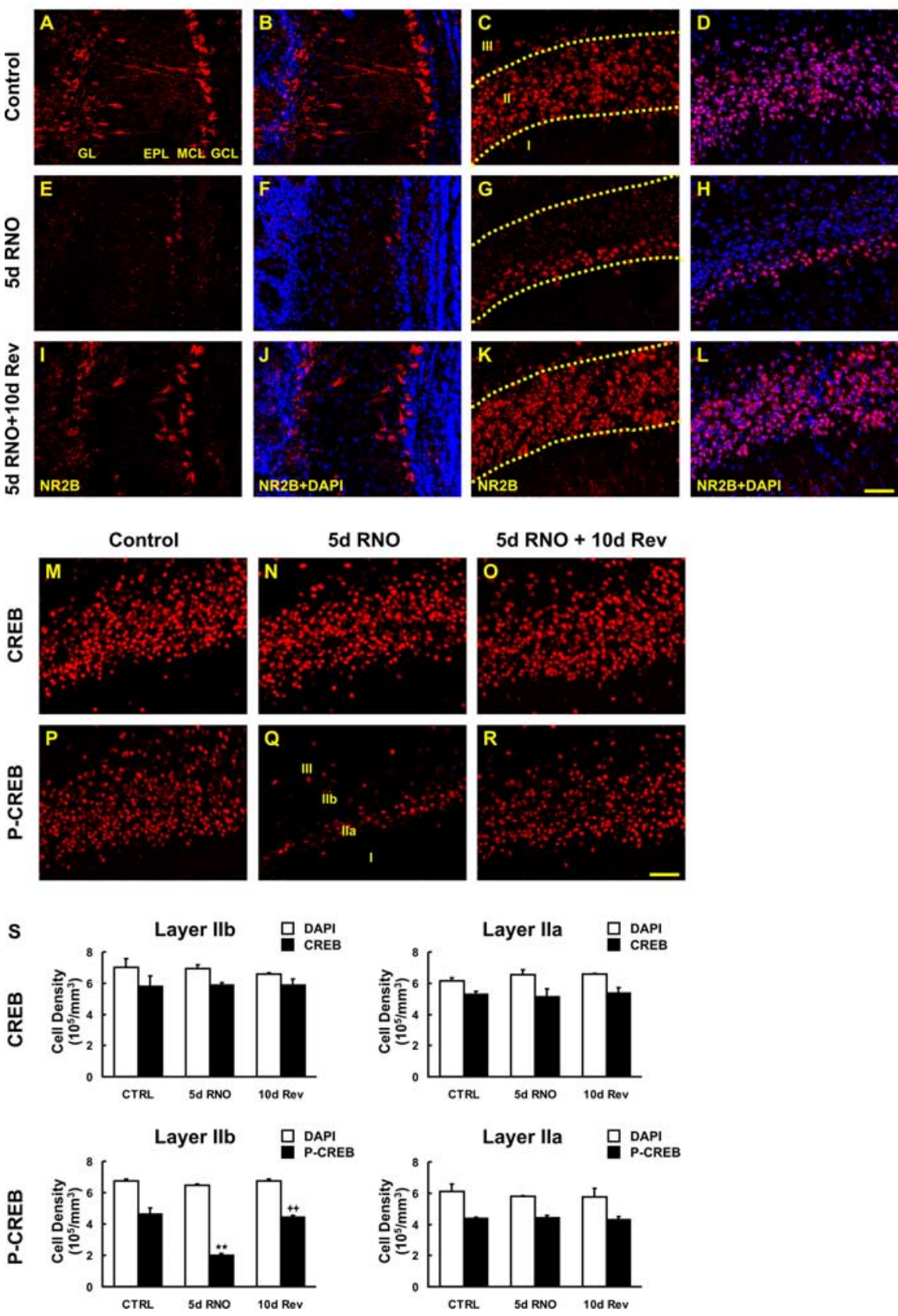

Figure 8. Recovery of deprivation-induced reduction of NR2B-expression and CREB phosphorylation. Sections from mice taken after 5 d of reversible naris occlusion (RN0) and $10 \mathrm{~d}$ of recovery (Rev) were processed for NR2B, CREB, and phospho-CREB (p-CREB) IHC. $\boldsymbol{A}-\boldsymbol{H}$, Reduction in NR2B immunoreactivity was observed in the deprived bulb $(\boldsymbol{E}, \boldsymbol{F})$ and its ipsilateral $\mathrm{PC}(\boldsymbol{G}, \boldsymbol{H})$ compared with the undeprived bulb $(\boldsymbol{A}, \boldsymbol{B})$ and its $P C(\boldsymbol{C}, \boldsymbol{D})$. I-L, NR2B expression was also recovered to the same as control at $10 \mathrm{~d}$ after reinstatement in $\mathrm{OB}(\boldsymbol{I}, \boldsymbol{J})$ and $\mathrm{PC}(\boldsymbol{K}, \boldsymbol{L}) . \boldsymbol{N}, \mathbf{Q}, \boldsymbol{R}$, After $5 \mathrm{~d}$ RN0, phospho-CREB immunostaining $(\mathbf{Q})$ but not CREB $(\boldsymbol{N})$ was reduced in layer $\mathrm{Ilb}$ and this reduction was reversed at $10 \mathrm{~d}$ after removal of plugs $(\boldsymbol{R})$. $\boldsymbol{S}$, The density of total nuclei and CREB/phosphoCREB-positive cells per unit volume was stereologically quantified in layers lla (right) and llb (left) for CREB (top) and phosphoCREB (bottom). Five days after RN0, phospho-CREB-immunoreactive cell number was significantly reduced in layer llb compared with the control, and the recovery on retrieval of activity was significant $\left({ }^{* *} p<0.01\right)$. Data are means $+\operatorname{SEM}(n=3)$. Scale bar, $50 \mu \mathrm{m}$.

1998; Cummings et al., 2000) as well as nares closure (Brunjes et al., 1985; Cho et al., 1996; Jin et al., 1996; Liu et al., 1999; Hamilton and Coppola, 2003), alters gene expression in the olfactory bulb. However, reductions in sensory input may have wide effects by reducing activity not only in the olfactory bulb but also in higher-order olfactory areas such as the piriform cortex.

Plasticity is the ability of a nervous system to make adapta- tions in structure and function (Zilles, 1992). Peripheral activity-dependent regulation of transsynaptic events in cortex have been studied in the visual system (Wiesel and Hubel, 1963; Hubel and Wiesel, 1970) and the somatosensory system (Fox, 1992; Lu et al., 2001; Shepherd et al., 2003). The pioneering work of Wiesel and Hubel (Wiesel and Hubel, 1963; Hubel and Wiesel, 1970) demonstrated that visual sensory deprivation can influence the development of ocular dominance columns in the primary visual cortex. This activity-dependent cortical ocular dominance plasticity occurs during early postnatal development described as the "critical period" and was thought not to occur thereafter in adult animals (Hubel and Wiesel, 1970; Cynader et al., 1980; LeVay et al., 1980; Hensch, 2004). However, recently, adult visual plasticity has been reported when monocular deprivation is preceded by visual deprivation (He et al., 2006). It has been demonstrated that some neurotransmitters (Kasamatsu and Pettigrew, 1976; Shaw et al., 1986), receptors (Reiter and Stryker, 1988; Shaw and Cynader, 1988; Gu et al., 1989; Bear et al., 1990; Gu and Singer 1993), and growth factors (Domenici et al., 1991; Maffei et al., 1992; Gu et al., 1994) are involved in modulating ocular dominance plasticity. Plasticity in the olfactory system has been characterized on monosynaptic connections either from $\mathrm{OE}$ to $\mathrm{OB}$ or $\mathrm{OB}$ to $\mathrm{PC}$ showing functional (Margolis et al., 1974; Brunjes et al., 1985; Baker et al., 1988; Cho et al., 1996) as well as structural plasticity including cell proliferation (Heimer and Kalil, 1978; Farbman et al., 1988; Corotto et al., 1994; Najbauer and Leon, 1995; Cummings et al., 2000; Fiske and Brunjes 2001; Rochefort et al., 2002), axonal/dendritic growth (Brunjes, 1994; Wilson et al., 2000), and synaptic physiology (Guthrie et al., 1990; Philpot et al., 1997; Best and Wilson, 2003). Here, we document changes in CREB phosphorylation and expression of the NR2B gene after peripheral deafferentation (zinc sulfate lesion) and sensory deprivation (naris closure). In a model of reversible naris occlusion (Fig. 8), the expression changes in NR2B are fully rescued after reopening of the naris. The present study is the first demonstration of transsynaptic plasticity in the olfactory system from the periphery to the cortex, demonstrating activitydependent gene expression in second order synapses in the adult PC.

\section{Contribution of different synaptic connections to transsynaptic plasticity}

The piriform cortex is divided into three layers based on cytoarchitecture and afferent connections (Haberly and Price, 1978, 
Haberly and Behan, 1983). Most of the pyramidal cell bodies reside in layers II and III, and these cells receive inputs from mitral cells and other cortical areas having connections in layer I. Excitatory afferent connections are made in Ia and excitatory intrinsic connections in Ib (Zou et al., 2001). Layer II, the superficial compact cell layer, is also divided into two sublayers: the most superficial layer (IIa) has a lower cell density and the deeper division (IIb) has a higher cell density. Pyramidal cells in layers IIb and III each exhibit a single apical dendrite whose branches extend to layer I, multiple basal dendrites, a high concentration of dendritic spines, and a deeply directed axon, whereas pyramidal cells in layer IIa lack basal dendrites (O'Leary, 1937; Haberly, 1983). The early studies in rat described pyramidal cells in layers IIb and III as projecting back to granule cells in the main OB but those in layer IIa as sending their axons back to the AON (Haberly and Price, 1978). Based on this previous study in rat, we used FG retrograde tracing to demonstrate that pyramidal cells in layer IIb projected to $\mathrm{OB}$ and $\mathrm{CTb}$ injected into $\mathrm{AON}$ to demonstrate pyramidal cells in layer IIa in mice. With this technique, we were able to demonstrate that these two subsets of pyramidal cells participated in different synaptic circuits in the mouse. This is the first demonstration that differentiates layers IIa and IIb using two different tracers in mouse. This result also suggests that a reduction in OSN input to the bulb and subsequent reduction in bulb neural activity results in alteration to NMDA receptors, and neural excitability in pyramidal neurons involved in cortical feedback to the bulb.

\section{Effects of activity-dependent CREB-phosphorylation on neuronal gene expression}

Calcium influx through postsynaptic NMDA receptors can stimulate neuronal gene expression via signaling pathways such as the Ras-MAP kinase pathway and the transcription factor CREB (Bading and Greenberg, 1991; Ginty et al., 1993; Xia et al., 1996). CREB is widely implicated in synaptic plasticity and memory formation (Frank and Greenberg, 1994; Ghosh and Greenberg, 1995; Bito et al., 1997; Balschun et al., 2003). Phosphorylation of CREB at Ser-133 leads to recruitment of other components of the transcription machinery to CREs to regulate gene transcription (Bito, 1998; Shaywitz and Greenberg, 1999; Mayr and Montminy, 2001; Lonze and Ginty, 2002; Weeber and Sweatt, 2002; West et al., 2002). Phosphorylation of CREB on Ser-133 is critical for activating the transcription of genes controlled by the CRE element (Montminy, 1997; Sala et al., 2000), many of which may be involved in neuronal growth and plasticity (e.g., BDNF, CaMKIV (calmodulin-dependent protein kinase type IV), synapsin I, somatostatin, voltage-gated potassium channels, c-fos, and c-jun) (Sauerwald et al., 1990; Mori et al., 1993; Sassone-Corsi, 1995; Shieh et al., 1998; Tao et al., 1998). Consistent with this, we found an activity-dependent reduction of CREB-phosphorylation and a reduced expression of $\mathrm{c}-$ fos in $\mathrm{OB}$ and $\mathrm{PC}$. In contrast, the NR2B gene has a CREB binding site in its proximal promoter region, suggesting that changes in CREB-phosphorylation can also regulate NR2B expression (Sasner and Buonanno, 1996; Klein et al., 1998; Myers et al., 1999; Rani et al., 2005). These findings are of specific interest to us here in examining whether afferent stimulus manipulation leading to changes in NR2B gene regulation is transsynaptically linked to CREB-signaling pathways in neurons in the PC. Indeed, we observed reductions in CREB-phosphorylation as well as NR2B expression after deprivation. The results of the present study provide an insight to understanding the molecular mechanism of transsynaptic changes in gene expression in the olfactory system. CREB phosphorylation by itself is not synonymous with gene induction (Ginty, 1997). Therefore, a question that remains to be addressed is, whether the regulation of CREB-phosphorylation by NMDA receptors correlates with gene transcriptional responses. We have already answered this by demonstrating changes in c-fos and NR2B expression that are thought to be regulated by CREB. Because CREB has been implicated in learning and memory in the olfactory system (Yin et al., 1994, 1995), this study has important implications for understanding the underlying mechanisms of odor discrimination and memory.

In conclusion, the present study has provided the first demonstration for peripheral activity-dependent transsynaptic gene regulation in the PC of the olfactory system. These results provide initial insights to understanding the molecular mechanisms underlying neuronal plasticity in the olfactory system.

\section{References}

Bading H, Greenberg ME (1991) Stimulation of protein tyrosine phosphorylation by NMDA receptor activation. Science 253:912-914.

Baker H, Kawano T, Margolis FL, Joh TH (1983) Transneuronal regulation of tyrosine hydroxylase expression in olfactory bulb of mouse and rat. J Neurosci 3:69-78.

Baker H, Towle AC, Margolis FL (1988) Differential afferent regulation of dopaminergic and GABAergic neurons in the mouse main olfactory bulb. Brain Res 450:69-80.

Baker H, Morel K, Stone DM, Maruniak JA (1993) Adult naris closure profoundly reduces tyrosine hydroxylase expression in mouse olfactory bulb. Brain Res 614:109-116.

Balschun D, Wolfer DP, Gass P, Mantamadiotis T, Welzl H, Schutz G, Frey JU, Lipp HP (2003) Does cAMP response element-binding protein have a pivotal role in hippocampal synaptic plasticity and hippocampusdependent memory? J Neurosci 23:6304-6314.

Bear MF, Kleinschmidt A, Gu QA, Singer W (1990) Disruption of experience-dependent synaptic modifications in striate cortex by infusion of an NMDA receptor antagonist. J Neurosci 10:909-925.

Berkowicz DA, Trombley PQ, Shepherd GM (1994) Evidence for glutamate as the olfactory receptor cell neurotransmitter. J Neurophysiol 71:2557-2561.

Best AR, Wilson DA (2003) A postnatal sensitive period for plasticity of cortical afferents but not cortical association fibers in rat piriform cortex. Brain Res 961:81-87.

Bito H (1998) The role of calcium in activity-dependent neuronal regulation. Cell Calcium 23:143-150.

Bito H, Deisseroth K, Tsien RW (1997) $\mathrm{Ca}^{2+}$-dependent regulation in neuronal gene expression. Curr Opin Neurobiol 7:419-429.

Brunjes PC (1994) Unilateral naris closure and olfactory system development. Brain Res Rev 19:146-160.

Brunjes PC, Smith-Crafts LK, McCarty R (1985) Unilateral odor deprivation: effects on the development of olfactory bulb catecholamines and behavior. Brain Res 354:1-6.

Capurso SA, Calhoun ME, Sukhov RR, Mouton PR, Price DL, Koliatsos VE (1997) Deafferentation causes apoptosis in cortical sensory neurons in the adult rat. J Neurosci 17:7372-7384.

Casabona G, Catania MV, Storto M, Ferraris N, Perroteau I, Fasolo A, Nicoletti F, Bovolin P (1998) Deafferentation up-regulates the expression of the mGlula metabotropic glutamate receptor protein in the olfactory bulb. Eur J Neurosci 10:771-776.

Cho JY, Min N, Franzen L, Baker H (1996) Rapid down-regulation of tyrosine hydroxylase expression in the olfactory bulb of naris-occluded adult rats. J Comp Neurol 369:264-276.

Corotto FS, Henegar JR, Maruniak JA (1994) Odor deprivation leads to reduced neurogenesis and reduced neuronal survival in the olfactory bulb of the adult mouse. Neuroscience 61:739-744.

Cummings DM, Henning HE, Brunjes PC (1997) Olfactory bulb recovery after early sensory deprivation. J Neurosci 17:7433-7440.

Cummings DM, Emege DK, Small SL, Margolis FL (2000) The pattern of olfactory bulb-re-innervation returns following recovery from reversible peripheral deafferentation. J Comp Neurol 421:362-373.

Cynader MS, Timney BN, Mitchell DE (1980) Period of susceptibility of kitten visual cortex to the effects of monocular deprivation extends beyond six months of age. Brain Res 191:545-550.

de Freitas MF, McQuillen PS, Shatz CJ (2001) A novel p75NTR signaling pathway promotes survival, not death, of immunopurified neocortical subplate neurons. J Neurosci 21:5121-5129. 
de Olmos JS, Beltramino CA, de Olmos-de Lorenzo S (1994) Use of an amino-cupric-silver technique for the detection of early and semiacute neuronal degeneration caused by neurotoxicants, hypoxia, and physical trauma. Neurotoxicol Teratol 16:545-561.

Domenici L, Berardi N, Carmignoto G, Vantini G, Maffei L (1991) Nerve growth factor prevents the amblyopic effects of monocular deprivation. Proc Natl Acad Sci USA 88:8811-8815.

Duvoisin RM, Zhang C, Ramonell K (1995) A novel metabotropic glutamate receptor expressed in the retina and olfactory bulb. J Neurosci 15:3075-3083.

Ehlers MD, Kaplan DR, Price DL, Koliatsos VE (1995) NGF-stimulated retrograde transport of trkA in the mammalian nervous system. J Cell Biol 130:149-156.

Ennis M, Zimmer LA, Shipley MT (1996) Olfactory nerve stimulation activates rat mitral cells via NMDA and non-NMDA receptors in vitro. NeuroReport 7:989-992.

Farbman AI, Brunjes PC, Rentfro L, Michas J, Ritz S (1988) The effect of unilateral naris occlusion on cell dynamics in the developing rat olfactory epithelium. J Neurosci 8:3290-3295.

Fernandes AM, Maurer-Morelli CV, Campos CB, Mello ML, Castilho RF, Langone F (2004) Fluoro-Jade, but not Fluoro-Jade B, stains nondegenerating cells in brain and retina of embryonic and neonatal rats. Brain Res 1029:24-33.

Ferraris N, Perroteau I, De Marchis S, Fasolo A, Bovolin P (1997) Glutamatergic deafferentation of olfactory bulb modulates the expression of mGluR1a mRNA. NeuroReport 8:1949-1953.

Fiske BK, Brunjes PC (2001) Cell death in the developing and sensorydeprived rat olfactory bulb. J Comp Neurol 431:311-319.

Fox K (1992) A critical period for experience-dependent synaptic plasticity in rat barrel cortex. J Neurosci 12:1826-1838.

Frank DA, Greenberg ME (1994) CREB: a mediator of long-term memory from mollusks to mammals. Cell 79:5-8.

Franklin BJ, Paxinos GT (1997) The mouse brain in stereotaxic coordinates. New York: Academic.

Franks KM, Isaacson JS (2005) Synapse-specific downregulation of NMDA receptors by early experience: a critical period for plasticity of sensory input to olfactory cortex. Neuron 47:101-114.

Ghosh A, Greenberg ME (1995) Calcium signaling in neurons: molecular mechanisms and cellular consequences. Science 268:239-247.

Ginty DD (1997) Calcium regulation of gene expression: isn't that spatial? Neuron 18:183-186.

Ginty DD, Kornhauser JM, Thompson MA, Bading H, Mayo KE, Takahashi JS, Greenberg ME (1993) Regulation of CREB phosphorylation in the suprachiasmatic nucleus by light and a circadian clock. Science 260:238-241.

Giustetto M, Bovolin P, Fasolo A, Bonino M, Cantino D, Sassoe-Pognetto M (1997) Glutamate receptors in the olfactory bulb synaptic circuitry: heterogeneity and synaptic localization of $N$-methyl-D-aspartate receptor subunit 1 and AMPA receptor subunit 1. Neuroscience 76:787-798.

Grafe MR, Leonard CM (1980) Successful silver impregnation of degenerating axons after long survivals in the human brain. J Neuropathol Exp Neurol 39:555-574.

Gu QA, Singer W (1993) Effects of intracortical infusion of anticholinergic drugs on neuronal plasticity in kitten striate cortex. Eur J Neurosci 5:475-485.

Gu QA, Bear MF, Singer W (1989) Blockade of NMDA-receptors prevents ocularity changes in kitten visual cortex after reversed monocular deprivation. Brain Res Dev Brain Res 47:281-288.

Gu QA, Liu Y, Cynader MS (1994) Nerve growth factor-induced ocular dominance plasticity in adult cat visual cortex. Proc Natl Acad Sci USA 91:8408-8412.

Guthrie KM, Wilson DA, Leon M (1990) Early deprivation modifies olfactory bulb function. J Neurosci 10:3402-3412.

Guthrie KM, Anderson AJ, Leon M, Gall CM (1993) Odor-induced increases in c-fos mRNA expression reveal an anatomical "unit" for odor processing in olfactory bulb. Proc Natl Acad Sci USA 90:3329-3333.

Haberly LB (1983) Structure of the piriform cortex of the opossum. I. Description of neuron types with golgi methods. J Comp Neurol 213:163-187.

Haberly LB, Behan M (1983) Structure of the piriform cortex of the opossum. III. Ultrastructural characterization of synaptic terminals of association and olfactory bulb afferent fibers. J Comp Neurol 219:448-460.

Haberly LB, Price JL (1978) Association and commissural fiber systems of the olfactory cortex of the rat. J Comp Neurol 178:711-740.
Halasz N, Ljungdahl A, Hokfelt T, Johansson O, Goldstein M, Park D, Biberfeld P (1977) Transmitter histochemistry of the rat olfactory bulb. I. Immunohistochemical localization of monoamine synthesizing enzymes. Support for intrabulbar, periglomerular dopamine neurons. Brain Res 126:455-474.

Hall ED, Gibson TR, Pavel KM (2005) Lack of a gender difference in posttraumatic neurodegeneration in the mouse controlled cortical impact injury model. J Neurotrauma 22:669-679.

Hamilton KA, Coppola DM (2003) Distribution of GluR1 is altered in the olfactory bulb following neonatal naris occlusion. J Neurobiol 54:326-336.

He HY, Hodos W, Quinlan EM. Related Articles (2006) Visual deprivation reactivates rapid ocular dominance plasticity in adult visual cortex. J Neurosci 26:2951-2955.

Heimer L, Kalil R (1978) Rapid transneuronal degeneration and death of cortical neurons following removal of the olfactory bulb in adult rats. J Comp Neurol 178:559-609.

Hensch TK (2004) Critical period regulation. Annu Rev Neurosci 27:549-579.

Hopkins KJ, Wang GJ, Shumued LC (2000) Temporal progression of kainic acid induced neuronal and myelin degeneration in the rat forebrain. Brain Res 864:69-80.

Hubel DH, Wiesel TN (1970) The period of susceptibility to the physiological effects of unilateral eye closure in kittens. J Physiol (Lond) 206:419-436

Illig KR, Haberly LB (2003) Odor-evoked activity is spatially distributed in piriform cortex. J Comp Neurol 457:361-373.

Ishii T, Moriyoshi K, Sugihara H, Sakurada K, Kadotani H, Yokoi M, Akazawa C, Shigemoto R, Mizuno N, Masu M (1993) Molecular characterization of the family of the N-methyl-D-aspartate receptor subunits. J Biol Chem 268:2836-2843.

Jin BK, Franzen L, Baker H (1996) Regulation of c-Fos mRNA and fos protein expression in olfactory bulbs from unilaterally odor-deprived adult mice. Int J Dev Neurosci 14:971-982.

Kasamatsu T, Pettigrew JD (1976) Depletion of brain catecholamines: failure of ocular dominance shift after monocular occlusion in kittens. Science 194:206-209.

Kato H, Narita M, Miyatake M, Yajima Y, Suzuki T (2006) Role of neuronal NR2B subunit-containing NMDA receptor-mediated $\mathrm{Ca}^{2+}$ influx and astrocytic activation in cultured mouse cortical neurons and astrocytes. Synapse 59:10-17.

Kinoshita A, Shigemoto R, Ohishi H, van der Putten H, Mizuno N (1998) Immunohistochemical localization of metabotropic glutamate receptors, mGluR7a and mGluR7b, in the central nervous system of the adult rat and mouse: a light and electron microscopic study. J Comp Neurol 393:332-352.

Klein M, Pieri I, Uhlmann F, Pfizenmaier K, Eisel U (1998) Cloning and characterization of promoter and 5'-UTR of the NMDA receptor subunit epsilon 2: evidence for alternative splicing of $5^{\prime}$-non-coding exon. Gene 208:259-269.

Koliatsos VE, Price DL (1996) Axotomy as an experimental model of neuronal injury and cell death. Brain Pathol 6:447-465.

Koliatsos VE, Dawson TM, Kecojevic A, Zhou Y, Wang YF, Huang KX (2004) Cortical interneurons become activated by deafferentation and instruct the apoptosis of pyramidal neurons. Proc Natl Acad Sci USA 101:14264-14269.

Kupina NC, Detloff MR, Dutta S, Hall E (2002) The neuroimmunophilin ligand V-10,367 is neuroprotective following 24 -h delayed administration in a mouse model of diffuse traumatic brain injury. J Cereb Blood Flow Metab 22:1212-1221.

Leung CH, Wilson DA (2003) Trans-neuronal regulation of cortical apoptosis in the adult rat olfactory system. Brian Res 984:182-188.

LeVay S, Wiesel TN, Hubel DH (1980) The development of ocular dominance columns in normal and visually deprived monkeys. J Comp Neurol 191:1-51.

Liu N, Cigola E, Tinti C, Jin BK, Conti B, Volpe BT, Baker H (1999) Unique regulation of immediate early gene and tyrosine hydroxylase expression in the odor-deprived mouse olfactory bulb. J Biol Chem 274:3042-3047.

Lonze BE, Ginty DD (2002) Function and regulation of CREB family transcription factors in the nervous system. Neuron 35:605-623.

Lu HC, Gonzalez E, Crair MC (2001) Barrel cortex critical period plasticity is independent of changes in NMDA receptor subunit composition. Neuron 32:619-634.

Luo J, Wang Y, Yasuda RP, Dunah AW, Wolfe BB (1997) The majority of $\mathrm{N}$-methyl-D-aspartate receptor complexes in adult rat cerebral cortex 
contain at least three different subunits (NR1/NR2A/NR2B). Mol Pharmacol 51:79-86.

Maffei L, Berardi N, Domenici L, Parisi V, Pizzorusso T (1992) Nerve growth factor (NGF) prevents the shift in ocular dominance distribution of visual cortical neurons in monocularly deprived rats. J Neurosci 12:4651-4662.

Margolis FL, Roberts N, Ferriero D, Feldman J (1974) Denervation in the primary olfactory pathway of mice: biochemical and morphological effects. Brain Res 81:469-483.

Maruniak JA, Lin PJ, Henegar JR (1989) Effects of unilateral naris closure on the olfactory epithelia of adult mice. Brain Res 490:212-218.

Mayr B, Montminy M (2001) Transcriptional regulation by the phosphorylation-dependent factor CREB. Nat Rev Mol Cell Biol 2:599-609.

McBride K, Slotnick B, Margolis FL (2003) Does intranasal application of zinc sulfate produce anosmia in the mouse? An olfactometric and anatomical study. Chem Senses 28:659-670.

Montague AA, Greer CA (1999) Differential distribution of ionotropic glutamate receptor subunits in the rat olfactory bulb. J Comp Neurol 405:233-246.

Montminy M (1997) Transcriptional regulation by cyclic AMP. Annu Rev Biochem 66:807-822.

Mori H, Mishina M (1995) Structure and function of the NMDA receptor channel. Neuropharmacology 34:1219-1237.

Mori Y, Matsubara H, Folco E, Siegel A, Koren G (1993) The transcription of a mammalian voltage-gated potassium channel is regulated by cAMP in a cell-specific manner. J Biol Chem 268:26482-26493.

Myers SJ, Dingledine R, Borges K (1999) Genetic regulation of glutamate receptor ion channels. Annu Rev Pharmacol Toxicol 39:221-241.

Nadi NS, Head R, Grillo M, Hempstead J, Grannot-Reisfeld N, Margolis FL (1981) Chemical deafferentation of the olfactory bulb: plasticity of the levels of tyrosine hydroxylase, dopamine and norepinephrine. Brain Res 213:365-377.

Najbauer J, Leon M (1995) Olfactory experience modulates apoptosis in the developing olfactory bulb. Brain Res 674:245-251.

O'Leary JL (1937) Structure of the primary olfactory cortex of the mouse. J Comp Neurol 67:1-31.

Petralia RS, Wang YX, Singh S, Wu C, Shi L, Wei J, Wenthold RJ (1997) A monoclonal antibody shows discrete cellular and subcellular localizations of mGluR1 alpha metabotropic glutamate receptors. J Chem Neuroanat 13:77-93.

Philpot BD, Foster TC, Brunjes PC (1997) Mitral/tufted cell activity is attenuated and becomes uncoupled from respiration following naris closure. J Neurobiol 33:374-386.

Rani CS, Qiang M, Ticku MK (2005) Potential role of cAMP response element-binding protein in ethanol-induced $N$-methyl-D-aspartate receptor 2B subunit gene transcription in fetal mouse cortical cells. Mol Pharmacol 67:2126-2136.

Reiter HO, Stryker MP (1988) Neural plasticity without postsynaptic action potentials: less-active inputs become dominant when kitten visual cortical cells are pharmacologically inhibited. Proc Natl Acad Sci USA 85:3623-3627.

Rochefort C, Gheusi G Vincent JD, Liedo PM (2002) Enriched odor exposure increases the number of newborn neurons in the adult olfactory bulb and improves odor memory. J Neurosci 22:2679-2689.

Russ JC, Dehoff RT (1999) Practical stereology, Ed 2. New York: Plenum.

Sala C, Rudolph-Correia S, Sheng M (2000) Developmentally regulated NMDA receptor-dependent dephosphorylation of cAMP response element-binding protein (CREB) in hippocampal neurons. J Neurosci 20:3529-3536.

Salter MG, Fern R (2005) NMDA receptors are expressed in developing oligodendrocyte processes and mediate injury. Nature 438:1167-1171.

Sasner M, Buonanno A (1996) Distinct $N$-methyl-D-aspartate receptor 2B subunit gene sequences confer neuronal and developmental specific expression. J Biol Chem 271:21316-21322.

Sassone-Corsi P (1995) Transcription factors responsive to cAMP. Annu Rev Cell Dev Biol 11:355-377.

Sauerwald A, Hoesche C, Oschwald R, Kilimann MW (1990) The 5[prime]flanking region of the synapsin I gene. A G+C-rich, TATA- and CAATless, phylogenetically conserved sequence with cell type-specific promoter function. J Biol Chem 265:14932-14937.

Schumued LC, Hopkins KJ (2000) Fluoro-Jade B: a high affinity fluorescent marker for the localization of neuronal degeneration. Brain Res 874:123-130.
Schumued LC, Albertson C, Slikker Jr W (1997) Fluoro-Jade: a novel fluorochrome for the sensitive and reliable histochemical localization of neuronal degeneration. Brain Res 751:37-46.

Shaw C, Cynader M (1988) Unilateral eyelid suture increases GABAA receptors in cat visual cortex. Brain Res 468:148-153.

Shaw C, Wilkinson M, Cynader M, Needler MC, Aoki C, Hall SE (1986) The laminar distributions and postnatal development of neurotransmitter and neuromodulator receptors in cat visual cortex. Brain Res Bull 16:661-671.

Shaywitz AJ, Greenberg ME (1999) CREB: a stimulus-induced transcription factor activated by a diverse array of extracellular signals. Annu Rev Biochem 68:821-861.

Shepherd GM, Pologruto TA, Svoboda K (2003) Circuit analysis of experience-dependent plasticity in the developing rat barrel cortex. Neuron 38:277-289.

Shieh PB, Hu SC, Bobb K, Timmusk T, Ghosh A (1998) Identification of a signaling pathway involved in calcium regulation of BDNF expression. Neuron 20:727-740.

Shipley MT, Ennis M (1996) Functional organization of olfactory system. J Neurobiol 30:123-176.

Stone DM, Wessel T, Joh TH, Baker H (1990) Decrease in tyrosine hydroxylase, but not aromatic L-amino acid decarboxylase, messenger RNA in rat olfactory bulb following neonatal, unilateral odor deprivation. Brain Res Mol Brain Res 8:291-300.

Tao X, Finkbeiner S, Arnold DB, Shaywitz AJ, Greenberg ME (1998) $\mathrm{Ca}^{2+}$ influx regulates BDNF transcription by a CREB family transcription factor-dependent mechanism. Neuron 20:709-726.

Thomas GM, Huganir RL (2004) MAPK cascade signaling and synaptic plasticity. Nat Rev Neurosci 5:173-183.

Trombley PQ, Westbrook GL (1990) Excitatory synaptic transmission in cultures of rat olfactory bulb. J Neurophysiol 64:598-606.

van den Pol AN (1995) Presynaptic metabotropic glutamate receptors in adult and developing neurons: autoexcitation in the olfactory bulb. J Comp Neurol 359:253-271.

Wada E, Shigemoto R, Kinoshita A, Ohishi H, Mizuno N (1998) Metabotropic glutamate receptor subtypes in axon terminals of projection fibers from the main and accessory olfactory bulbs: a light and electron microscopic immunohistochemical study in the rat. J Comp Neurol 393:493-504.

West AE, Griffith EC, Greenberg ME (2002) Regulation of transcription factors by neuronal activity. Nat Rev Neurosci 3:921-931.

Weeber EJ, Sweatt JD (2002) Molecular neurobiology of human cognition. Neuron 33:845-848.

Wiesel TN, Hubel DH (1963) Single-cell responses in striate cortex of kittens deprived of vision in one eye. J Neurophysiol 26:1003-1017.

Wilson DA (1995) NMDA receptors mediate expression of one form of functional plasticity induced by olfactory deprivation. Brain Res 677:238-242.

Wilson DA, Sullivan RM, Gall CM, Guthrie KM (1996) NMDA-receptor modulation of lateral inhibition and c-fos expression in olfactory bulb. Brain Res 719:62-71.

Wilson DA, Best AR, Brunjes PC (2000) Trans-neuronal modification of anterior piriform cortical circuitry in the rat. Brain Res 853:317-322.

Xia Z, Dudek H, Miranti C, Greenberg M (1996) Calcium influx via the NMDA receptor induces immediate early gene transcription by a MAP kinase/ERK-dependent mechanism. J Neurosci 16:5425-5436.

Yamamoto T, Iwasaki Y, Konno H, Iizuka H (1986) Identification of cells undergoing physiological neuronal death in the neonatal rat brain by the Fink-Heimer method. Brain Res 374:419-424.

Yin JC, Wallach JS, del Vecchio M, Wilder EL, Zhou H, Quinn WG, Tully T (1994) Induction of a dominant negative CREB transgene specifically blocks long-term memory in Drosophila. Cell 79:49-58.

Yin JC, del Vecchio M, Zhou H, Tully T (1995) CREB as a memory modulator: induced expression of a dCREB2 activator isoform enhances longterm memory in Drosophila. Cell 81:107-115.

Zhu JJ, Qin Y, Zhao M, Van Aelst L, Malinow R (2002) Ras and Rap control AMPA receptor trafficking during synaptic plasticity. Cell 110:443-455.

Zilles K (1992) Neuronal plasticity as an adaptive property of the central nervous system. Ann Anat 174:383-391.

Zou Z, Horowitz LF, Montmayeur JP, Snapper S, Buck LB (2001) Genetic tracing reveals a stereotyped sensory map in the olfactory cortex. Nature 414:173-179. 